\title{
Synthesis of amines by the electrophilic amination of organomagnesium, -zinc, -copper, and -lithium reagents
}

\author{
Tahir Daşkapan \\ Department of Chemistry, Ankara University Science Faculty, 06100 Beşevler, Ankara, Turkey \\ E-mail:daskapan@science.ankara.edu.tr
}

Dedicated to Professor William F. Bailey on occasion of his $65^{\text {th }}$ birthday

\section{Contents}

1. Introduction

2. Electrophilic Amination of Organomagnesium Reagents

3. Electrophilic Amination of Organozinc Reagents

4. Electrophilic Amination of Organocopper Reagents

5. Electrophilic Amination of Organolithium Reagents

6. Conclusions

7. Acknowledgement

8. References

\section{Introduction}

Amines are important building blocks in the synthesis of various important organic compounds such as pharmaceuticals, agrochemicals, polymers, dyes, xerographic and photographic materials. ${ }^{1-5}$ Therefore, development of new synthetic methods for amines has attracted the attention of many researchers. ${ }^{6-11}$ Among modern amination methods, electrophilic amination of an easily available organometallic reagent has been found to be a viable alternative method and continues to be an active area for research in synthetic organic chemistry. ${ }^{12-16}$

To date various type of aminating reagents have been used in the electrophilic amination of organomagnesium, -zinc, -copper, and -lithium reagents for the introduction of free or protected amino moieties, such as haloamines, substituted hydroxylamines, imines, oxaziridines, oximes, diazonium salts, azodicarboxylates, azides, and metal amides. This review covers the literature published in the last twenty years in detail. In addition, older literature has been mentioned briefly. 


\section{Electrophilic Amination of Organomagnesium Reagents}

Haloamines were one of the earliest aminating reagent class used for the amination of organomagnesium reagents. ${ }^{17-22}$ But, reaction of Grignard reagents with haloamines resulted in low yields because of the formation of other amines and ammonia as byproducts with expected amines. ${ }^{23-25}$ Therefore, haloamines have not received much attention as aminating reagents in the amination of Grignard reagents.

Recently, two successful procedures for the preparation of tertiary amines by electrophilic amination of Grignard reagents with $N$-chloroamines have been published. One of them was described by Sinha and Knochel. ${ }^{26}$ They treated functionalized arylmagnesium reagents, which were prepared by a $\mathrm{Br}-\mathrm{Mg}$ or I-Mg exchange by the reaction of $\mathrm{ArBr}$ or ArI with $i-\mathrm{PrMgCl} . \mathrm{LiCl}$, with benzyl- $N$-chloroamines at $-45^{\circ} \mathrm{C}$ to synthesize polyfunctional tertiary amines in good yields (Scheme 1). They also prepared a chiral tertiary amine from the corresponding chiral $\mathrm{N}$ chloroamine with retention of chirality applying this procedure, but the yield was low (34\%). Amination of 3-pyridylmagnesium chloride also gave a low yield (27\%).

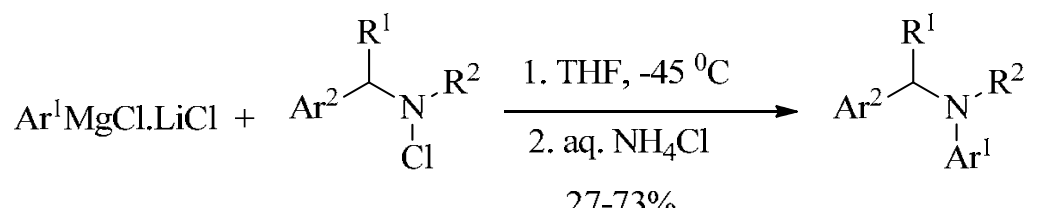

$$
\begin{aligned}
& \mathrm{R}^{\mathrm{I}}=\mathrm{H}, \mathrm{Me} \\
& \mathrm{R}^{2}=\mathrm{Me}, \mathrm{Et}, n-\mathrm{Hex} \\
& \mathrm{Ar}^{\mathrm{I}}=\mathrm{C}_{6} \mathrm{H}_{5}, 4-\mathrm{MeO}_{2} \mathrm{CC}_{6} \mathrm{H}_{4}, 2-\mathrm{EtO}_{2} \mathrm{CC}_{6} \mathrm{H}_{4}, 4-\mathrm{NCC}_{6} \mathrm{H}_{4} \text {, } \\
& \text { 3- } \mathrm{NCC}_{6} \mathrm{H}_{4}, 4-\mathrm{IC}_{6} \mathrm{H}_{4}, 3-\text { pyridyl } \\
& \mathrm{Ar}^{2}=\mathrm{C}_{6} \mathrm{H}_{5}, 4-\mathrm{BrC}_{6} \mathrm{H}_{4} \text {, 1-naphtyl }
\end{aligned}
$$

\section{Scheme 1}

Another methodology for the amination of organomagnesium compounds with $\mathrm{N}$ chloroamines has been published in 2010 by Hatakeyama and co-workers. ${ }^{27}$ In this procedure, tertiary amines were prepared by the reaction of aryl- and heteroarylmagnesium bromides with various $N$-chloroamines at $-40^{\circ} \mathrm{C}$ in the presence of TMEDA (Scheme 2). 

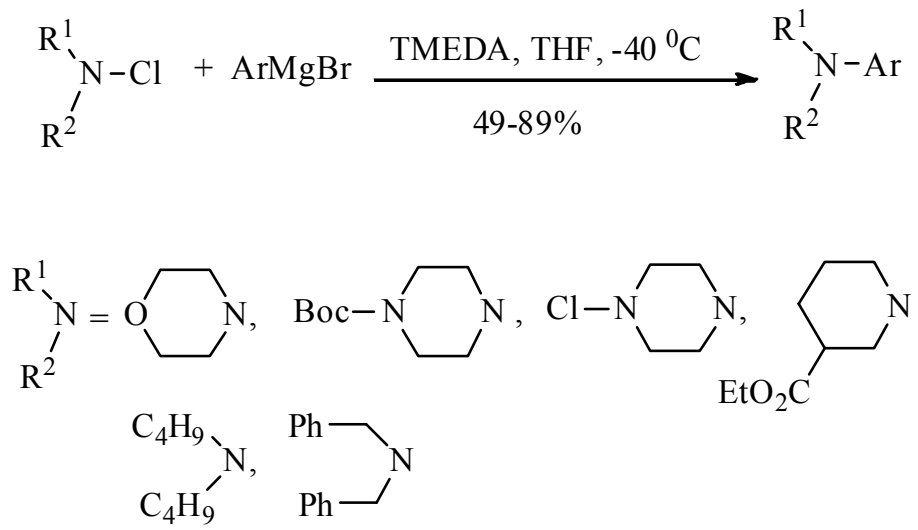

$\mathrm{Ar}=\mathrm{C}_{6} \mathrm{H}_{5}, 4-\mathrm{MeC}_{6} \mathrm{H}_{4}, 4-\mathrm{MeC}_{6} \mathrm{H}_{4}, 4-\mathrm{NCC}_{6} \mathrm{H}_{4}, 4$-pyridyl

\section{Scheme 2}

It is observed that the amination reaction was unsuccessful in the absence of TMEDA or in the presence of other additives, such as TMPDA, DABCO, HMTA, PMDTA and DME. The success of the amination reaction in the presence of TMEDA was attributed to the formation of a transition state which can be stabilized by electrostatic interaction between the negatively charged chloride atom of $N$-chloramine and the magnesium atom (Scheme 3 ).

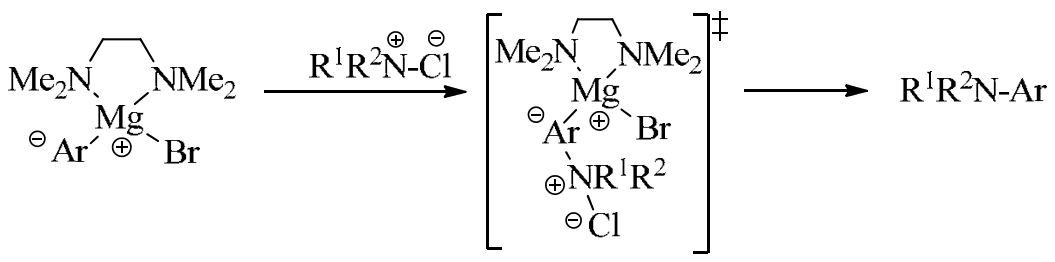

\section{Scheme 3}

The amination of Grignard reagents with methoxyamine was first shown by Schverdina and Kotscheschkow. ${ }^{28,29}$ They obtained alkyl and arylamines in good to high yields at $-15{ }^{\circ} \mathrm{C}$. Then methoxyamine was used by several research groups for the electrophilic amination of various organomagnesium compounds. ${ }^{30-32}$ Reaction of alkylmagnesium reagents with $\mathrm{LiNHOCH}_{3}$ was found to be unsuccessful. ${ }^{33,34}$

Preparation of aniline by the electrophilic amination of phenylmagnesium bromide using $O$ phenylhydroxylamine as aminating reagent was achieved in high yield. ${ }^{35}$

Some $N, N$-dialkyl- $O$-sulfonylhydroxylamines were reacted with organomagnesium reagents to prepare tertiary amines. But the yields of expected amines were not high. ${ }^{36}$ Reaction of 1alkynylmagnesium bromides with $\quad \mathrm{N}, \mathrm{N}$-dimethyl-O-(methylsulfonyl)hydroxylamine $\left(\mathrm{Me}_{2} \mathrm{NOSO}_{2} \mathrm{Me}\right)$ was unsuccessful. ${ }^{37}$ 
Recently, Erdik and Ateş described a Barbier-Grignard-type amination procedure for organomagnesium reagents with $N, N$-dimethyl-O-(mesitylenesulfonyl)hydroxylamine. ${ }^{38}$ Synthesis of some $N, N$-dimethylanilines with high yields has succeeded (Scheme 4) but amination of cyclo-alkyl-, allyl-, and benzylmagnesium reagents failed.

$$
\begin{aligned}
& \mathrm{ArBr}+\mathrm{Mg}+\mathrm{Me}_{2} \mathrm{NOSO}_{2} \mathrm{Mes} \frac{\text { 1. THF, r.t., } 2 \text { h. }}{\text { 2. aq. sat. } \mathrm{NaHCO}_{3}} \mathrm{Me}_{2} \mathrm{NAr} \\
& \mathrm{Ar}=\mathrm{C}_{6} \mathrm{H}_{5}, 4-\mathrm{MeC}_{6} \mathrm{H}_{4}, 3-\mathrm{MeC}_{6} \mathrm{H}_{4}, 2-\mathrm{MeC}_{6} \mathrm{H}_{4}, 4-\mathrm{MeOC}_{6} \mathrm{H}_{4}, 3-\mathrm{MeOC}_{6} \mathrm{H}_{4} \\
& \mathrm{Me}_{2} \mathrm{NAr} \text {, yields }=60-83 \%
\end{aligned}
$$

\section{Scheme 4}

Most $O$-acylhydroxylamines are not stable at room temperature because of their tendency to isomerize to hydroxamic acids. Therefore, they have not been used so much in the electrophilic amination of carbanions. Copper-II catalyzed reaction of various $\mathrm{N}, \mathrm{N}$-dialkyl-Obenzoylhydroxylamines with organomagnesium reagents have been shown by Champbell and Johnson. ${ }^{39} \mathrm{RMgX}$ was added slowly $(0.15 \mathrm{mmol} / \mathrm{min}$. $)$ to the mixture of aminating reagent and copper catalyst in THF at room temperature. Tertiary amines were obtained in low to high yields (Scheme 5). But synthesis of secondary amines and $N$-phenylindole under these reaction conditions failed. It was observed that organomagnesium reagents attacked the $\mathrm{C}$-atom of aminating reagents to form benzophenone, benzhydrol and triphenylmethanol as predominant products in the absence of copper catalysis. But aminating reagents bearing large acyl groups, such as $2,4,6-\mathrm{Me}_{3} \mathrm{PhCO}_{2} \mathrm{NEt}_{2}$, gave tertiary amines as the major product $(85 \%)$.

$$
\begin{gathered}
\mathrm{R}^{1} \mathrm{R}^{2} \mathrm{NOBz} \frac{\mathrm{R}^{3} \mathrm{MgX} \text { (Slow addition) }}{\mathrm{THF}, \mathrm{CuCl}_{2}(2.5 \text { or } 10 \%), \mathrm{rt}} \begin{array}{r}
\mathrm{R}^{1} \mathrm{R}^{2} \mathrm{NR}^{3} \\
58-95 \%
\end{array} \\
\mathrm{R}^{1} \mathrm{R}^{2} \mathrm{~N}=\mathrm{Bn}_{2} \mathrm{~N}, \mathrm{Et}_{2} \mathrm{~N},(\text { allyl })_{2} \mathrm{~N} \text {, morpholin-4-yl, 1-piperidyl } \\
\mathrm{R}^{3}=\mathrm{Et},{ }^{c} \mathrm{Hex},{ }^{t} \mathrm{Bu}, \mathrm{C}_{6} \mathrm{H}_{5}, 4-\mathrm{FC}_{6} \mathrm{H}_{4}, 2-\mathrm{MeC}_{6} \mathrm{H}_{4}, 4-\mathrm{MeOC}_{6} \mathrm{H}_{4}, \\
\text { 2,4,6- } \mathrm{Me}_{3} \mathrm{C}_{6} \mathrm{H}_{2}
\end{gathered}
$$

\section{Scheme 5}

$O$-(diphenylphosphinyl)hydroxylamine is stable at $-20^{\circ} \mathrm{C}$. It was reacted with various Grignard reagents at low temperature to prepare primary amines. ${ }^{40,41}$ A higher yield of amine was obtained when $\mathrm{RMgCl}$ was used instead of $\mathrm{RMgBr}$.

Organomagnesium reagents are the reagents of choice for $\mathrm{N}$-alkylation reactions of $\alpha$-imino esters. $^{42}$ The first studies on this subject were published by Fiaud and Kagan. ${ }^{43,44}$ They observed that primary Grignard reagents showed the highest regioselection in favor of the N-alkylation. 
Reaction of allyl and crotyl Grignard reagents with imino ester $\mathbf{1}$ resulted in C-alkylation. ${ }^{45,46}$ Benzylic Grignard reagents gave only the N-alkylation product. ${ }^{47}$

Reaction of tert-BuMgCl with $\alpha$-imino ester $1^{48}$ resulted in very poor regioselectivity at -78 ${ }^{\circ} \mathrm{C}$ (Scheme 6). When the reaction was performed at $20^{\circ} \mathrm{C}, \mathrm{C}$-alkylated product was obtained predominantly.

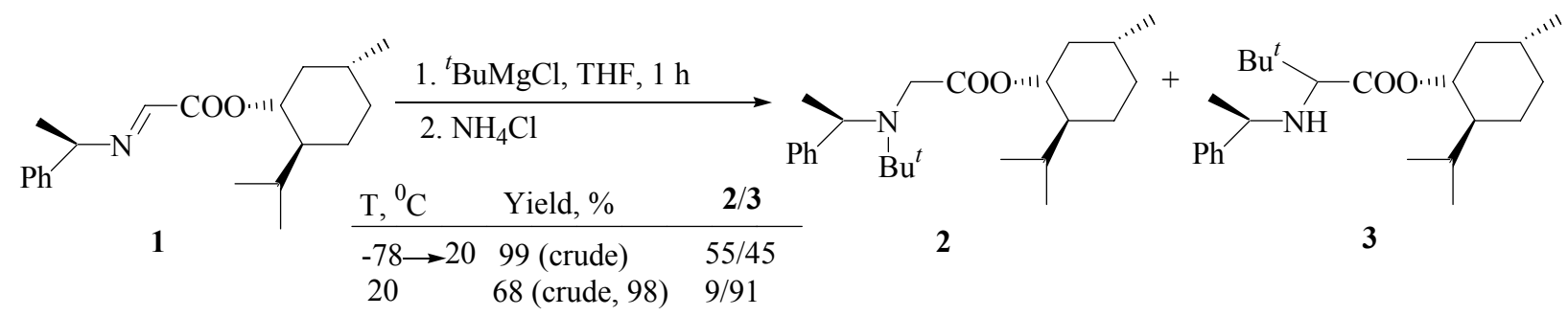

\section{Scheme 6}

Recently, 2-[N-(p-methoxyphenyl)imino]malonate $\mathbf{4}$ has been introduced as an efficient aminating reagent for the electrophilic amination of organomagnesium reagents (Scheme 7). ${ }^{49,50}$

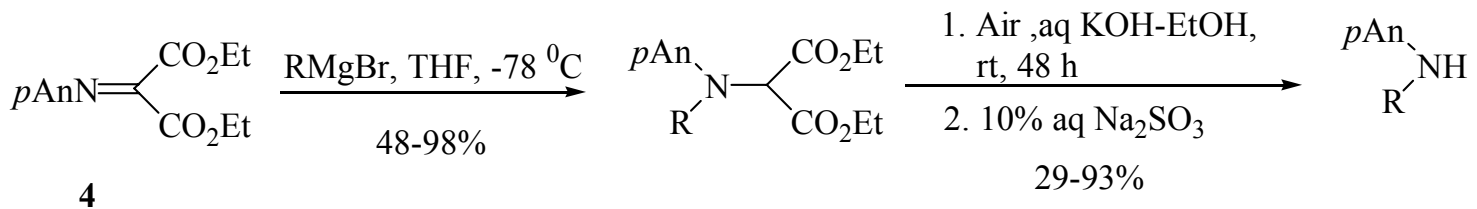

$$
\begin{aligned}
& p \mathrm{An}=4-\mathrm{CH}_{3} \mathrm{OC}_{6} \mathrm{H}_{4} \\
& \mathrm{R}=\text { primary alkyl, secondary alkyl, tertiary alkyl, cycloalkyl, aryl }
\end{aligned}
$$

\section{Scheme 7}

The mechanism of this amination reaction was predicted to be as shown in Scheme 8 . In the first step, organomagnesium reagent coordinates to the carbonyl group of iminomalonate 4. By this way the electron density of nitrogen atom is decreased. Then the alkyl group attacks the nitrogen atom to form the magnesium enolate. Hydrolysis of this enolate gives the desired amine.

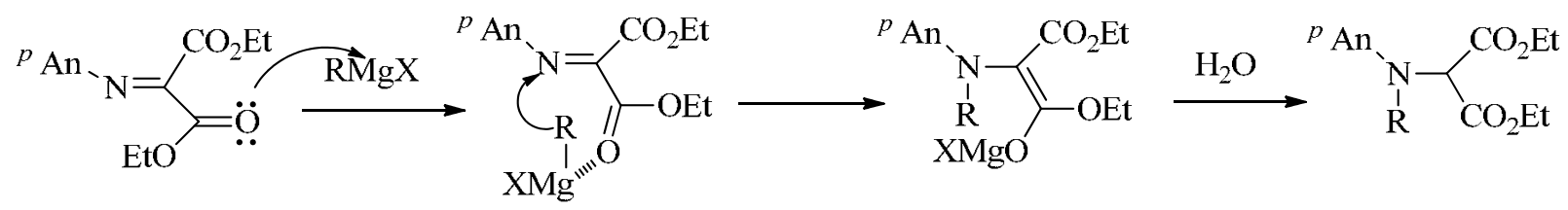

4

\section{Scheme 8}


THF was found to be the most suitable solvent for the N-alkylation reaction. Iodosylbenzene and air oxygen were the most effective oxidants for the oxidation of $\mathrm{N}$-alkylated products. But in the case of oxidation with air, it was necessary to use $10 \%$ aqueous $\mathrm{Na}_{2} \mathrm{SO}_{3}$ for the work-up procedure otherwise oxygen was not effective.

The highest yields were obtained with primary Grignard reagents. Cyclohexyl-, benzyl-, phenyl-, isopropyl-, and tert-butylmagnesium bromides gave $\mathrm{N}$-alkylation in low yields at -78 ${ }^{\circ} \mathrm{C}$, but in higher yields at $-95^{\circ} \mathrm{C}$.

Oximes are a class of aminating reagents which have been widely used in the electrophilic amination of organomagnesium reagents. There are a limited number of works which employ aldoximes as the aminating reagent in the electrophilic amination of organomagnesium reagents. $^{51,52}$

Attention has been focused on the amination with ketoximes. ${ }^{53-57}$

Among a number of O-substituted ketoximes $\left(\mathrm{R}_{2} \mathrm{C}=\mathrm{NOX}, \mathrm{X}=\mathrm{H}, \mathrm{CH}_{3},\left(\mathrm{CH}_{3}\right)_{3} \mathrm{Si}\right.$, Ts, $\mathrm{MesSO}_{2}$ ) acetone $O$-(2,4,6-trimethylphenylsulfonyl)oxime 5a was found to be a useful reagent for the amination of arylmagnesium reagents (Scheme 9, Method A). ${ }^{58,59}$ Treatment of phenylmagnesium bromide with 5a in diethyl ether-toluene $(1: 6$ by volume $)$ at $75{ }^{\circ} \mathrm{C}$ gave aniline in $58 \%$ yield after $40 \mathrm{~h}$. Addition of $10 \mathrm{~mol} \% \mathrm{CuI}$ or $20 \mathrm{~mol} \% \mathrm{MgCl}_{2}$ as catalyst to the reaction mixture decreased the reaction time to $11 \mathrm{~h}$ and $22 \mathrm{~h}$, respectively, without a significant change in the yield.

Reaction of aryl bromides with 5a and magnesium in THF under Barbier conditions allowed preparation of arylamines almost in the same or higher yields as those obtained by the procedure described above after $3 \mathrm{~h}$ without the need for any catalyst (Scheme 9, Method B). ${ }^{60}$ Arylamines were synthesized by simultaneous addition of THF solutions of the aryl bromide and 5a to magnesium and then heating the mixture under reflux for $3 \mathrm{~h}$.

$$
\begin{array}{ll}
\mathrm{ArX}+\mathrm{Mg} \stackrel{\mathrm{THF}}{\longrightarrow} \operatorname{ArMgX} \frac{75^{\circ} \mathrm{C}, 11-22 \mathrm{~h}}{2.6 \mathrm{~N} \mathrm{HCl}, 60{ }^{\circ} \mathrm{C}, 12 \mathrm{~h}} \\
\mathrm{ArX}+\mathrm{Mg}+\left(\mathrm{CH}_{3}\right)_{2} \mathrm{C}=\mathrm{NOMes} & \begin{array}{l}
\text { 1. THF, } 75{ }^{\circ} \mathrm{C}, 3 \mathrm{~h} \\
\text { 5a }
\end{array}
\end{array}
$$

\begin{tabular}{lccc}
\multirow{2}{*}{$\mathrm{Ar}$} & $\begin{array}{l}\text { Catalyst, \% } \\
\text { (for method A) }\end{array}$ & \multicolumn{2}{c}{$\mathrm{ArNH}_{2}, \%$} \\
\cline { 3 - 4 } & Method A & Method B \\
\hline $\mathrm{C}_{6} \mathrm{H}_{5}$ & $\mathrm{CuI}, 10$ & 59 & 52 \\
$4-\mathrm{CH}_{3} \mathrm{C}_{6} \mathrm{H}_{4}$ & $\mathrm{MgCl}_{2}, 10$ & 56 & 53 \\
4- $\mathrm{CH}_{3} \mathrm{OC}_{6} \mathrm{H}_{4}$ & $\mathrm{MgCl}_{2}, 20$ & 38 & 56 \\
1-naphthyl & $\mathrm{MgCl}_{2}, 20$ & 2 & 40
\end{tabular}

\section{Scheme 9}


Narasaka and coworkers used benzophenone $O$-sulfonyloxime derivatives having electronwithdrawing groups (Scheme 10) for the electrophilic amination of alkyl, cycloalkyl and arylmagnesium reagents. ${ }^{61-63} 4,4$ '-Bis(trifluoromethyl)benzophenone $O$-methylsulfonyloxime $6 \mathbf{6}$ reacts with primary-, secondary-, tertiary- and cyclo-alkylmagnesium reagents in THF-HMPA, at $0{ }^{\circ} \mathrm{C}$ and in the presence of $\mathrm{CuCN} .2 \mathrm{LiCl}$ as catalyst, to furnish the corresponding amines in high yields. Furthermore, amination of 1-norbornylmagnesium chloride and 1-adamantylmagnesium bromide under these reaction conditions resulted in high yields (82 and 96\%, respectively). But in the case of phenylmagnesium bromide the Würtz reaction occurred instead of an amination reaction and aniline formed only in 7\% yield but mainly biphenyl in 74\% yield.

$n$-Butylamine and 1-norbornylamine were prepared in 99\% and 96\% yields, respectively, using 4,4'-bis(trifluoromethyl)benzophenone $O$-p-tolylsulfonyloxime $\mathbf{6 b}$ under reaction conditions of amination with $\mathbf{6 a}$. The success of the reaction of $\mathbf{6 b}$ with aryl Grignard reagents in the absence of copper catalyst, depends on the solvent used in the preparation of arylmagnesium reagent. In the case of $\mathrm{PhMgBr} / \mathrm{THF}$, amination reaction resulted in $34 \%$ yield, but reaction with $\mathrm{PhMgBr}$ prepared in diethyl ether afforded the desired product in $62 \%$ yield.

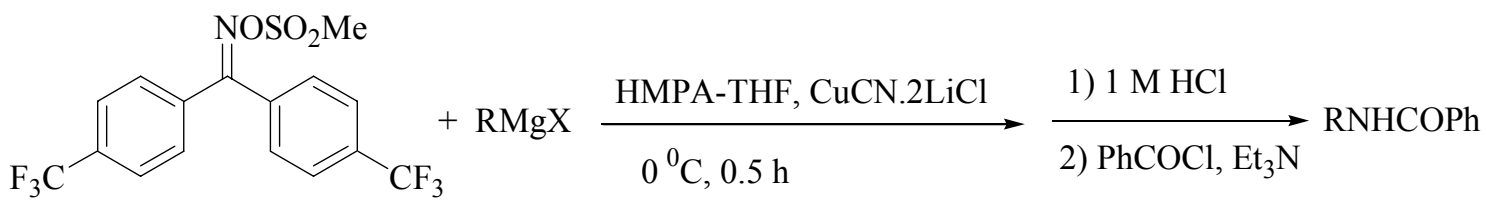

6a

$$
\begin{aligned}
& \mathrm{R}=n \text {-Bu, } i \text {-Pr, } c \text {-Hex, } t \text {-Bu, } 1 \text {-adamantyl } \\
& \text { Yield, } \%=96, \quad 93, \quad 80,61, \quad 82
\end{aligned}
$$

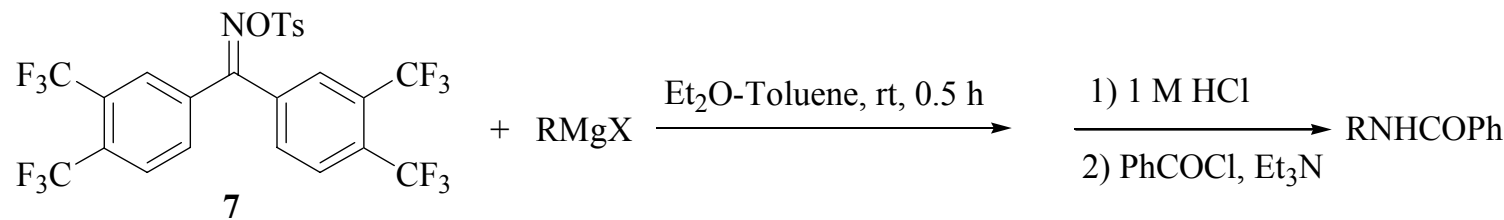

$\mathrm{R}=\mathrm{C}_{6} \mathrm{H}_{5}, 2-\mathrm{MeOC}_{6} \mathrm{H}_{4}, 3-\mathrm{MeOC}_{6} \mathrm{H}_{4}, 4-\mathrm{MeOC}_{6} \mathrm{H}_{4}, 4-\mathrm{FC}_{6} \mathrm{H}_{4}, 2,5-\mathrm{Me}_{2} \mathrm{C}_{6} \mathrm{H}_{3}, 1$-naphthyl, Et, $c-\mathrm{Hex}, t-\mathrm{Bu}$

Yield, $\%=96, \quad 72, \quad 94, \quad 98, \quad 96, \quad 98, \quad 96, \quad 87, \quad 87, \quad 35$

\section{Scheme 10}

Similar observations were obtained in the reaction of arylmagnesium reagents with 3,3',5,5'tetrakis(trifluoromethylphenyl)benzophenone $O$-p-tolylsulfonyloxime 7 and functional group containing arylamines were prepared in high yields by the use of corresponding arylmagnesium reagents prepared in diethyl ether (Scheme 10).

$O$-Sulfonyloximes of ureas and carbonates were screened for the electrophilic amination of organomagnesium reagents. ${ }^{64}$ It was determined that, in the reaction of diethyl carbonate $O$ - 
tosyloxime $\mathbf{8}$ with phenylmagnesium bromide in toluene, the organomagnesium reagent attacked either oxime carbon or the nitrogen atom to afford a mixture of $\mathbf{9 a - c}$ and $\mathbf{8}$ (Eq. 1).

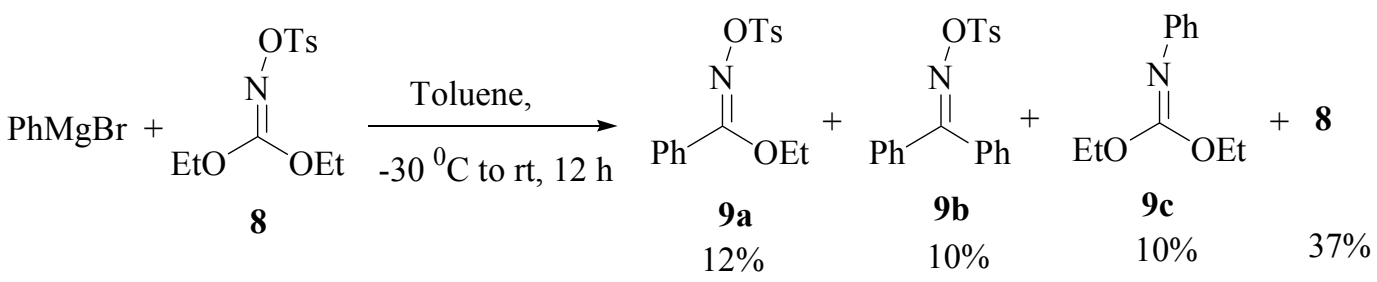

Cyclic urea and carbonate $O$-sulfonyloximes 10-12 (Scheme 11) were reacted with phenylmagnesium bromide and $\mathbf{1 0}$ was determined as the most useful aminating reagent for the amination of Grignard reagents prepared in diethyl ether. This oxime is more reactive in toluene as compared to THF. While the Z-isomer of oxime 12 gave only the $\mathrm{N}$-phenylation product, the $E$-isomer gave C-phenylation reaction.

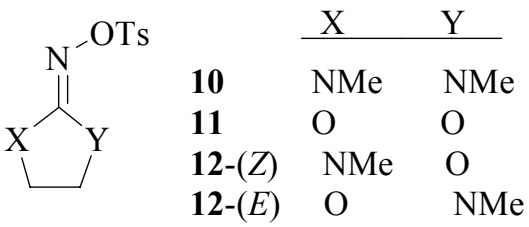

\section{Scheme 11}

Conversion of imine, formed after amination reaction, to aniline under acidic conditions failed. It is found that it can be selectively converted into aniline in high yield by treatment with $\mathrm{CsOH} . \mathrm{H}_{2} \mathrm{O}$ in ethylene glycol at $150{ }^{\circ} \mathrm{C}$ for $1 \mathrm{~h}$ or to $\mathrm{N}$-methylaniline in high yield by the reduction with $\mathrm{LiAlH}_{4}$ in THF at room temperature for $12 \mathrm{~h}$.

Primary, secondary and tertiary (except $t$-Bu) alkylmagnesium bromides reacted with compound 10 at $-78{ }^{\circ} \mathrm{C}$, and heteroaryl and functional groups bearing arylmagnesium bromides at $0{ }^{\circ} \mathrm{C}$ to give the corresponding imines, which upon hydrolysis or reduction provide the corresponding amines or $N$-methylamines, respectively, in good to high yields (Scheme 12). But the hydrolysis and reduction of 2,6-dimethylphenylimine and 4-trifluoromethylphenylimine could not be achieved. In addition, 2-thienylimine could not be converted to the primary amine. 
1) $\mathrm{CsOH} . \mathrm{H}_{2} \mathrm{O}$, ethylene glycol

$\underbrace{\frac{\mathrm{RMgBr} \text {, toluene, } \mathrm{Et}_{2} \mathrm{O}}{0{ }^{0} \mathrm{C}-\mathrm{rt} \text { or }-78^{\circ} \mathrm{C}}}_{\mathrm{NMe}}$

10

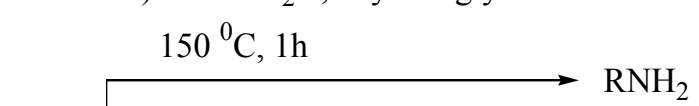

2) $\mathrm{HCl} / \mathrm{Et}_{2} \mathrm{O}$ $36-98 \%$

$\mathrm{LiAlH}_{4}, \mathrm{Et}_{2} \mathrm{O}, \mathrm{THF}, \mathrm{rt}$ or reflux $\longrightarrow \mathrm{RMeNH}$ $55-93 \%$

$$
\begin{aligned}
\mathrm{R}= & \mathrm{C}_{6} \mathrm{H}_{5}, 2-\mathrm{MeOC}_{6} \mathrm{H}_{4}, 2-\mathrm{MeC}_{6} \mathrm{H}_{4}, 2,6-\mathrm{Me}_{2} \mathrm{C}_{6} \mathrm{H}_{3}, 2,4-(\mathrm{MeO})_{2} \mathrm{C}_{6} \mathrm{H}_{3}, 4-\mathrm{F}_{3} \mathrm{CC}_{6} \mathrm{H}_{4} \\
& \text { 2-thienyl, phenethyl, 1-phenyl-but-3-yl, 1-adamantyl, 1-naphthyl }
\end{aligned}
$$

\section{Scheme 12}

Narasaka's group screened various 1,3-dioxolan-2-one $O$-sulfonyloximes 13a-d (Scheme 13) and introduced 4,4,5,5-tetramethyl-1,3-dioxalan-2-one $O$-phenylsulfonyloxime 13a as a more appropriate aminating reagent for organomagnesium reagents than $O$-sulfonyloximes mentioned above. $^{65}$

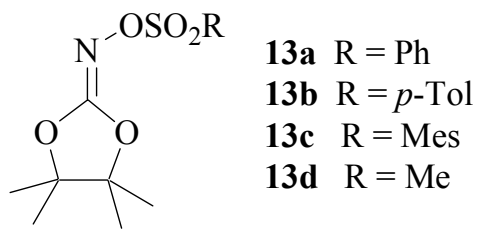

\section{Scheme 13}

Compound 13a reacted with aryl and functionalized arylmagnesium reagents prepared in $\mathrm{Et}_{2} \mathrm{O}$ at room temperature in dichloromethane or at $0{ }^{\circ} \mathrm{C}$ in chlorobenzene to afford the corresponding arylamines in excellent yields after the hydrolysis of the resulting imines with $1 \mathrm{M} \mathrm{HCl}$ in $\mathrm{Et}_{2} \mathrm{O}$ (Scheme 14). Amination of arylmagnesium reagents prepared in THF completed in a longer time while amination in THF was not efficient. Alkyl and cycloalkylmagnesium reagents also reacted with 13a to supply the desired products in high yields after the hydrolysis of the resulting $N$-alkyl imines under reflux in acidic EtOH. Amination of styryl and isopropenylmagnesium reagents was achieved in excellent yields. 


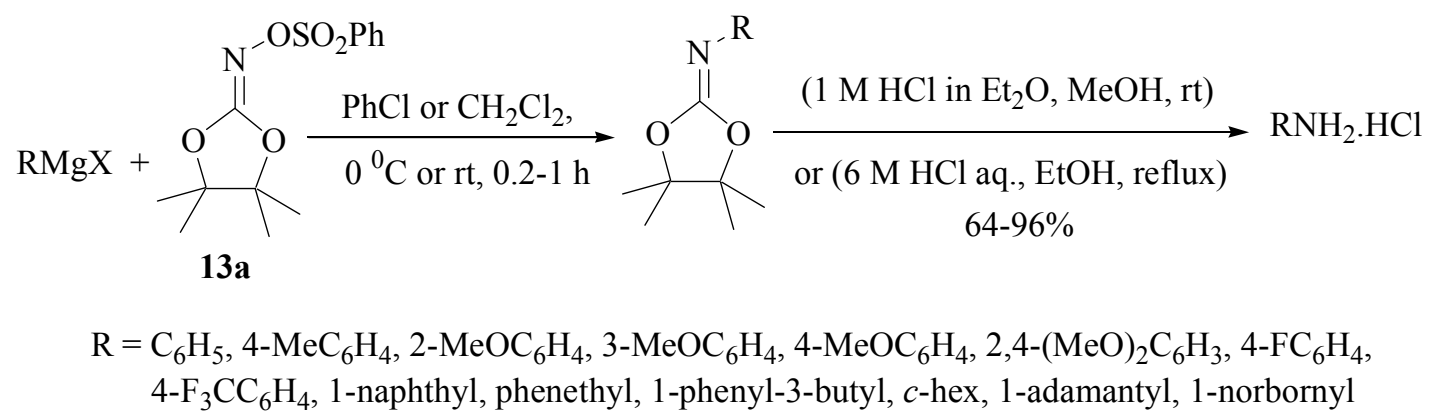

\section{Scheme 14}

Organomagnesium reagents react with azides to give magnesium salts of 1,3-disubstituted triazenes which can be converted to amines by appropriate reduction or hydrolysis methods. ${ }^{66-69}$ Various azides were used for the electrophilic amination of organomagnesium reagents.

Functionalized aryl Grignard reagents, prepared in THF, give an exothermic reaction with tosyl azide. Treatment of the reaction mixture with Raney nickel and cold aqueous $\mathrm{NaOH}$ gives aniline derivatives in yields of up to $82 \% .^{70}$

Arylmagnesium reagents, prepared in ether, can be aminated at room temperature using trimethylsilylmethyl azide in good to high yields. ${ }^{71}$ Phenylmagnesium bromide gives two parallel reactions with triphenylsilyl azide. ${ }^{72}$ One of these reactions is the substitution of the azide group by the phenyl group of the Grignard reagent to form tetraphenylsilane. The other reaction is the formation of the corresponding triazene salt. Decomposition of this salt at $100-120^{\circ} \mathrm{C}$, followed by the hydrolysis of the resulting $N$-(triphenylsily1)amide gives aniline.

Attack of Grignard reagents on azides, bearing electron-withdrawing groups, was assumed to be facilitated by coordination between $\mathrm{MgBr}_{2}$ as shown in Figure $1 .^{73}$ Trost and Pearson showed that, in the reaction of $\mathrm{RYCH}_{2} \mathrm{~N}_{3}$ (R: aryl, alkyl, Y: S, O) type heteroatom substituted azides with organomagnesium reagents, the activating influence of sulfur is higher than that of oxygen. In addition they observed that (arylthio)methyl azide was more successful than (alkylthio)methyl azide. $^{74}$

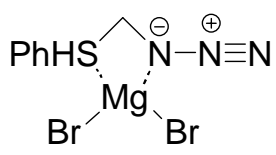

\section{Figure 1}

Addition of benzyl or butyl azide to the alkylmagnesium reagent in diethyl ether solution provides the corresponding triazene. ${ }^{69}$

Allyl azide 14 can easily be prepared by the reaction of sodium azide with allyl bromide in water in the presence of a catalytic amount of tetrabutylammonium bromide. ${ }^{75}$ It is used successfully as a synthon for ${ }^{+\delta} \mathrm{NH}_{2}$ in the synthesis of arylamines by the electrophilic amination 
of arylmagnesium reagents (Scheme 15$).{ }^{76}$ It is reported that azide 14 can be used without purification, but in this case the molar ratio of $\mathrm{ArMgX}: 14$ must be change from 1:1 to 1:1.5.

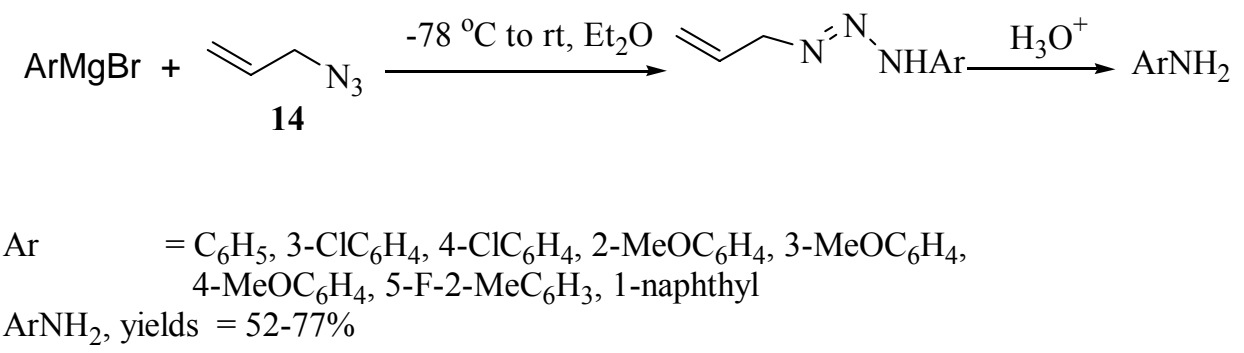

\section{Scheme 15}

Alkyl Grignard reagents add to aryl azides to form the corresponding mono- $N$-alkylanilines in high yields (Scheme 16). ${ }^{77}$ The method works effectively with Grignard reagent bearing both primary and secondary alkyl groups and aliphatic alkyl groups of different chain length. The formation of mono- $N$-alkylaniline as the only product (no trace of $N, N$-dialkylaniline) is attributed to the addition of the Grignard reagent to the azide with successive loss of $\mathrm{N}_{2}$, followed by proton capture during aqueous workup to form mono- $N$-alkylanilines. However, reaction of aryl Grignard reagents with aryl azide afforded the corresponding diazene. This different result was thought to be due to steric factors.

$$
\begin{aligned}
\mathrm{RMgBr}+ & \mathrm{Ar}_{3} \frac{\mathrm{N}_{3}}{\text { 1) } \mathrm{Et}_{2} \mathrm{O}, \mathrm{rt}, 0.5-1.5 \mathrm{~h}} \\
\text { 2) saturatede } \mathrm{NH}_{4} \mathrm{Cl} & \text { Ar-NH-R } \\
82-90 \% & \\
\mathrm{R}= & \mathrm{Et}, i \text { - } \mathrm{Pr}, n \text {-Bu, } c \text {-Hex, } n \text { - } \mathrm{Pr}, n \text {-heptyl, } n \text {-octyl, } n \text {-decyl, } \\
& n \text {-pentyl, } n \text {-dodecyl } \\
\mathrm{Ar}= & \mathrm{C}_{6} \mathrm{H}_{5}, 4-\mathrm{MeC}_{6} \mathrm{H}_{4}, 4-\mathrm{FC}_{6} \mathrm{H}_{4}, 4-\mathrm{ClC}_{6} \mathrm{H}_{4}, 4-\mathrm{MeOC}_{6} \mathrm{H}_{4}, \\
& 3,4-\mathrm{Cl}_{2} \mathrm{C}_{6} \mathrm{H}_{3}, \text { piperonyl, 2-naphthyl }
\end{aligned}
$$

\section{Scheme 16}

Reaction of arylmagnesium reagents with benzendiazonium chloride-zinc chloride double salt, in diethyl ether, resulted in very low yields (4-29\%). ${ }^{78-80}$ However, the yield was higher in THF which has stronger coordination ability. ${ }^{81}$

Arylazo tosylates which can be prepared in a two step-sequence consisting of a diazotation and tosylation of the resulting diazonium tetrafluoroborates, have been used as synthetic equivalents of the electrophilic arylamino synthon in the electrophilic amination of polyfunctional arylmagnesium reagents. ${ }^{82}$ Polyfunctional diarylamines can be prepared by the addition of functionalized arylmagnesium reagents to functionalized arylazo tosylates, followed by in situ allylation and reductive workup (Scheme 17). 


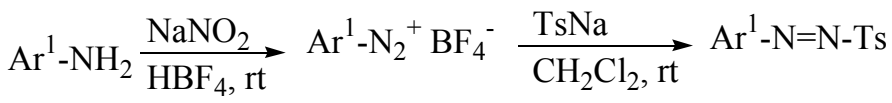

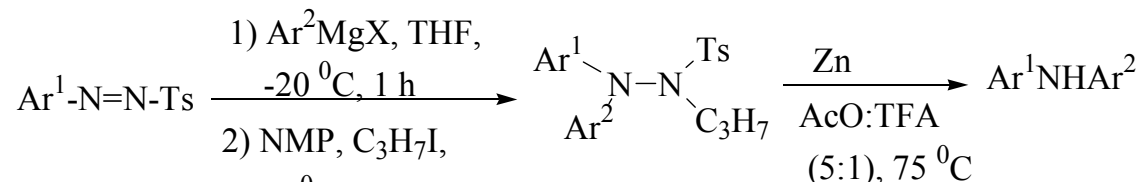

$$
\begin{aligned}
& 20{ }^{0} \mathrm{C}, 3 \mathrm{~h} \\
& 63-86 \% \\
& \mathrm{Ar}^{1}=4-\mathrm{EtO}_{2} \mathrm{CC}_{6} \mathrm{H}_{4}, 4-\mathrm{BrC}_{6} \mathrm{H}_{4}, 4-\mathrm{MeOC}_{6} \mathrm{H}_{4}, 4-\mathrm{IC}_{6} \mathrm{H}_{4}, 3-\mathrm{TfOC}_{6} \mathrm{H}_{4}, 2,4,6-\mathrm{Me}_{3} \mathrm{C}_{6} \mathrm{H}_{2} \\
& \mathrm{Ar}^{2}=4-\mathrm{IC}_{6} \mathrm{H}_{4}, 4-\mathrm{TfOC}_{6} \mathrm{H}_{4}, 2-\mathrm{CO}_{2} \mathrm{EtC}_{6} \mathrm{H}_{4}, 4-\mathrm{EtO}_{2} \mathrm{CC}_{6} \mathrm{H}_{4}, 4-\mathrm{BrC}_{6} \mathrm{H}_{4}, 2-\mathrm{BrC}_{6} \mathrm{H}_{4} \text {, } \\
& 4-\mathrm{MeOC}_{6} \mathrm{H}_{4}, 4-\mathrm{NCC}_{6} \mathrm{H}_{4}
\end{aligned}
$$

\section{Scheme 17}

Amination of 3-indolylmagnesium chloride, ferrocenylmagnesium bromide and cyclopropylmagnesium bromide was achieved using this amination procedure.

Knochel and co-workers ${ }^{83}$ described a procedure for the preparation of polyfunctionalized diarylamines by the reaction of arylmagnesium reagents with nitroarenes (Scheme 18). In this procedure not only organomagnesium reagent but also nitroarene can bear either electronwithdrawing or electron-donating groups. 6-Nitrobenzothiazole and 6-nitroquinoline can be arylated using this procedure to obtain the desired arylated amines in good yields.

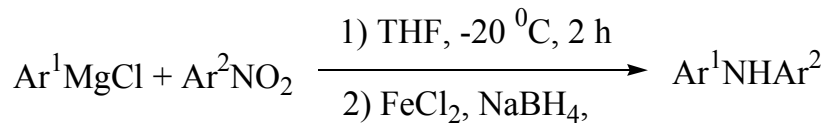

$$
\begin{aligned}
& -20{ }^{0} \mathrm{C} \text { to rt, } 2 \mathrm{~h} \\
& 63-86 \% \\
& \mathrm{Ar}^{1}=4-\mathrm{EtO}_{2} \mathrm{CC}_{6} \mathrm{H}_{4}, 4-\mathrm{MeOC}_{6} \mathrm{H}_{4}, 4-\mathrm{IC}_{6} \mathrm{H}_{4}, 3-\mathrm{NCPh} \\
& \mathrm{Ar}^{2}=4-\mathrm{EtO}_{2} \mathrm{CC}_{6} \mathrm{H}_{4}, 4-\mathrm{BrC}_{6} \mathrm{H}_{4}, 3-\mathrm{MeOC}_{6} \mathrm{H}_{4}, 3-\mathrm{NCC}_{6} \mathrm{H}_{4}
\end{aligned}
$$

\section{Scheme 18}

In the first step of the mechanism (Scheme 19) addition of the first equivalent of arylmagnesium reagent, followed by the elimination of magnesium phenolate, gives nitrosobenzene. The second equivalent of arylmagnesium reagent attacks the $\mathrm{N}=\mathrm{O}$ double bond of nitrosobenzene to form diarylhydroxylamine which is reduced to diarylamine (Scheme 19, path A). 


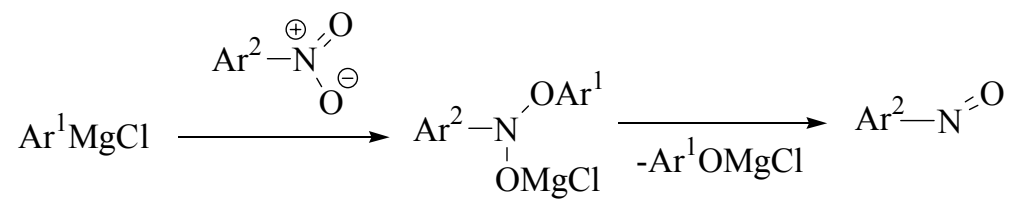

\section{Scheme 19}

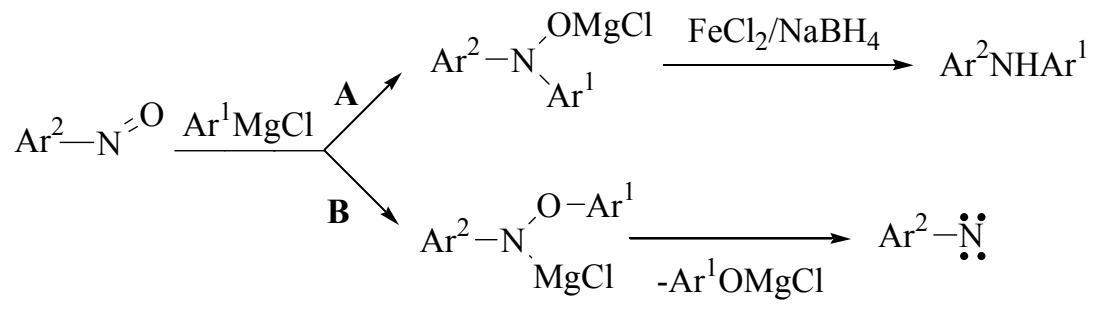

In the case of nitroarenes bearing a bulky substituent next to their nitro group, the second equivalent of arylmagnesium reagent attacks the oxygen atom of the nitroso arene (Scheme 19, path B) to form the corresponding nitrene. ${ }^{84}$ The amount of arylmagnesium reagent can be decreased from 2.3 equivalents to 1.2 equivalents by the use of nitroso arenes as starting materials (Scheme 20). ${ }^{85}$

$$
\begin{aligned}
& \mathrm{Ar}^{1} \mathrm{MgCl} \stackrel{\mathrm{Ar}^{2}-\mathrm{N}^{\prime} \mathrm{O}}{\longrightarrow} \mathrm{Ar}^{2}-\mathrm{N}_{-}^{\prime} \mathrm{Ar}^{1} \frac{\mathrm{OMgCl}}{\text { 2) } \mathrm{FeCl}_{2} / \mathrm{NaBH}_{4}, \mathrm{rt}, 2 \mathrm{~h}} \mathrm{Ar}^{2} \mathrm{NHAr}^{1} \\
& \text { 3) } \mathrm{H}_{2} \mathrm{O} \\
& 42-74 \% \\
& \mathrm{Ar}^{1}=\mathrm{C}_{6} \mathrm{H}_{5}, 4-\mathrm{EtO}_{2} \mathrm{CC}_{6} \mathrm{H}_{4}, 4-\mathrm{MeOC}_{6} \mathrm{H}_{4}, 4-\mathrm{IC}_{6} \mathrm{H}_{4} \text {, } \\
& \text { 4- } \mathrm{BrC}_{6} \mathrm{H}_{4}, 3-\mathrm{NCC}_{6} \mathrm{H}_{4}, 2-\mathrm{Me}_{2} \mathrm{NC}_{6} \mathrm{H}_{4} \\
& \mathrm{Ar}^{2}=\mathrm{C}_{6} \mathrm{H}_{5}, 2-\mathrm{MeC}_{6} \mathrm{H}_{4}, 4-\mathrm{Me}_{2} \mathrm{NC}_{6} \mathrm{H}_{4}, 3-\mathrm{NCC}_{6} \mathrm{H}_{4}
\end{aligned}
$$

\section{Scheme 20}

\section{Electrophilic Amination of Organozinc Reagents}

Organozinc compounds are an important class of main-group organometallic reagents. ${ }^{86-88}$ The bond between carbon and zinc has a covalent character and therefore they show modest reactivity towards many electrophilic reagents. This characteristic allows them to tolerate numerous functional groups. ${ }^{89}$

To date, only a few electrophilic amination procedures have been reported in the literature employing organozinc reagents. Coleman and coworkers reacted dialkylzinc reagents with chloroamines and obtained the desired amine as a mixture with other amines and ammonia ${ }^{21,90}$ 
Recently, a successful study related to the preparation of tertiary amines by the electrophilic amination of diorganozinc reagents with various $N, N$-dialkyl- $N$-chloroamines has been published by Barker and Jarvo. ${ }^{91}$ Diphenylzinc reagent was reacted with chloroamines using bipyridineligated Nickel catalyst. The reaction was carried out in DMA/THF (1:2.4) mixture at $0{ }^{\circ} \mathrm{C}$ and tertiary amines were obtained in moderate to high yields (Scheme 21a). This procedure has a functional group tolerance. For example amination of substrates which have terminal alkene or amide function, using this procedure resulted in good yields of the corresponding tertiary amines.

Amination of electron-poor $N, N$-dialkyl- $N$-chloroamines such as $N$-chloroamides and $N$ chlorosuccinimide under these reaction conditions was found to be unsuccessful. Amination of arylzinc chloride at room temperature gave tertiary amine in moderate yield $(55 \%)$, but at $0{ }^{\circ} \mathrm{C}$ in high yield $(87 \%)$.

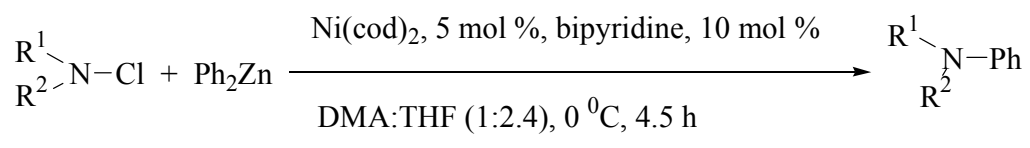

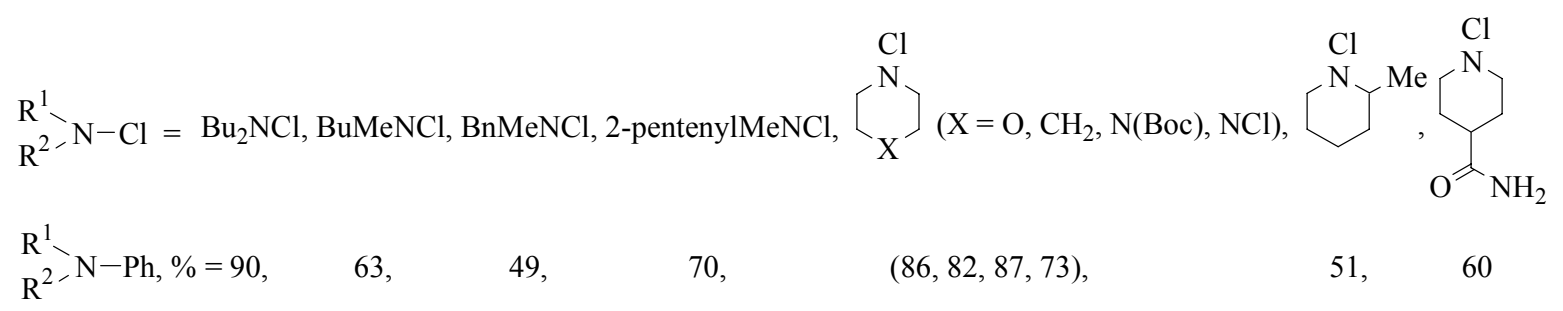

\section{Scheme 21a}

Functional group bearing diorganozinc reagents were also successfully aminated under these reaction conditions (Scheme 21b).

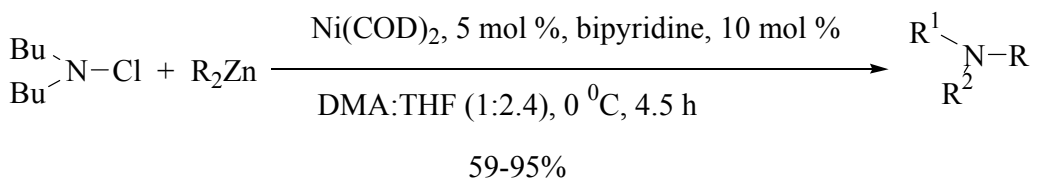

$$
\begin{aligned}
& \mathrm{R}=4-\mathrm{MeC}_{6} \mathrm{H}_{4}, 4-\mathrm{MeOC}_{6} \mathrm{H}_{4}, 3,4-(\mathrm{MeO})_{2} \mathrm{C}_{6} \mathrm{H}_{3} \text {, } \\
& 3-\mathrm{F}_{3} \mathrm{CC}_{6} \mathrm{H}_{4}, 4-\mathrm{FC}_{6} \mathrm{H}_{4} \text {, 2-thienyl }
\end{aligned}
$$

\section{Scheme 21b}

Secondary amines can be converted into tertiary amines by a one-pot chlorination and arylation reaction using this procedure (Scheme 22). 


$$
\begin{aligned}
& \mathrm{R}^{1}-\mathrm{N}-\mathrm{H} \underset{\mathrm{N}}{\stackrel{\text { 2) } \mathrm{Ni}(\mathrm{cod})_{2}, 5 \mathrm{~mol} \% \text {, bipyridine, } 10 \mathrm{~mol} \%}{\longrightarrow}} \stackrel{\mathrm{R}^{1} \backslash \mathrm{N}-\mathrm{Ph}}{\underset{\mathrm{R}^{2}}{\stackrel{\mathrm{N}}{2}}} \\
& \mathrm{Ph}_{2} \mathrm{Zn} \text { ( } 2 \text { equiv) } \\
& \text { DMA:THF (1:2.4), } 0{ }^{0} \mathrm{C}, 4.5 \mathrm{~h} \\
& \mathrm{R}^{2}-\mathrm{N}-\mathrm{H}=\underset{\mathrm{Bu}^{\prime}}{\mathrm{Bu}},\left[\begin{array}{l}
\mathrm{N} \\
\mathrm{O}
\end{array}\right],[ \\
& \begin{array}{l}
\mathrm{R}^{1}-\mathrm{N}-\mathrm{Ph}, \%=\quad 79, \\
\mathrm{R}^{2} \%
\end{array}
\end{aligned}
$$

\section{Scheme 22}

$N$-substituted $O$-benzoyl hydroxylamines and $N, N$-disubstituted $O$-benzoyl hydroxylamines have been used as $\mathrm{RNH}^{+\delta}$ and $\mathrm{R}_{2} \mathrm{~N}^{+\delta}$ synthons, respectively, in the synthesis of secondary and tertiary amines by the copper (II)-catalyzed electrophilic amination of diorganozinc reagents, ${ }^{92-94}$ prepared by $\mathrm{Li}-\mathrm{Zn}$ or $\mathrm{MgBr}-\mathrm{Zn}$ transmetallation or by directed ortho-metallation, and Nickelcatalyzed electrophilic amination of organozinc halides. ${ }^{95}$ In the amination of diorganozincs, aryl, heteroaryl, benzyl, $n$-alkyl, sec-alkyl, and tert-alkyl nucleophiles couple with aminating reagents to give the desired amines in good to high yields (Scheme 23).

$$
\text { }
$$

\section{Scheme 23}

Copper-catalyzed amination of diorganozincs is an exothermic reaction. This warming does not affect the reaction yield in micro-scale. However when the reaction is performed on a largescale it causes a decrease in yield (for example from $91 \%$ to $72 \%$ ) if the reaction temperature is not kept at $5{ }^{\circ} \mathrm{C} .{ }^{96}$ 
$[\mathrm{Cu}(\mathrm{OTf})]_{2} \cdot \mathrm{C}_{6} \mathrm{H}_{6}, \mathrm{Ni}(\mathrm{cod})_{2}$, and $\mathrm{Ni}(\operatorname{cod})_{2} /$ ligand were found to be not effective in the amination of organozinc halides with $\mathrm{N}, \mathrm{N}$-disubstituted- $O$-benzoylhydroxylamines. $\left(\mathrm{Ph}_{3} \mathrm{P}\right)_{2} \mathrm{NiCl}_{2}$ allowed preparation of tertiary amines in good to high yields (Scheme 24). ${ }^{92,95}$

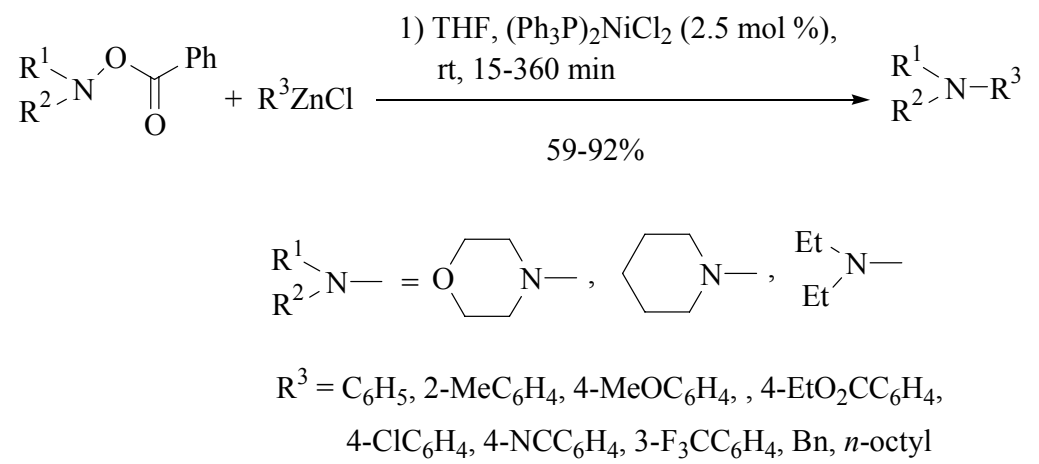

\section{Scheme 24}

$s-\mathrm{Bu}\left(\mathrm{CH}_{3}\right)_{2} \mathrm{ZnLi}$, type mixed zincate reacts with lithioalkoxylamides to furnish $s-\mathrm{BuNH}_{2}$ in low yield (18\%). ${ }^{34}$

$\mathrm{CuCN}$ catalyzed amination of diorganozincs and triorganozincates with methoxyamine $\mathbf{1 5}$ gives primary arylamines and benzylamine in moderate to high, alkyl and cycloalkyl amines in low to moderate yields. ${ }^{97,98}$ Addition of a dipolar aprotic solvent as cosolvent leads to an increase in the yields of arylamines and improves the reaction conditions. ${ }^{99}$ In the case of arylzinc chlorides, amination of functional group bearing arylzinc chloride is more successful than that of phenylzinc chloride (Scheme 25).

$$
\begin{aligned}
& \mathrm{RM}+\mathbf{5 a}, \mathbf{5 b}, \mathbf{1 5} \underset{\text { 1) } \mathrm{THF}, \mathrm{CS}, \mathrm{CuCN} \text {, r.t., 1-3h }}{\longrightarrow} \text { PhCONHR } \\
& \text { 2) Concd } \mathrm{HCl} \\
& \text { 3) } \mathrm{PhCOCl} \\
& \mathrm{M}=\mathrm{ZnCl}, 1 / 2 \mathrm{Zn}, 1 / 3 \mathrm{ZnMgBr} \\
& \mathrm{R}=\mathrm{C}_{6} \mathrm{H}_{5}, 4-\mathrm{MeC}_{6} \mathrm{H}_{4}, 4-\mathrm{MeOC}_{6} \mathrm{H}_{4}, 1 \text {-naphthyl, } n \text {-Bu, } c \text {-hex, Bn } \\
& \mathbf{5 a}, \mathbf{5 b}, \mathbf{1 5}=\left(\mathrm{CH}_{3}\right)_{2} \mathrm{C}=\mathrm{NOSO}_{2} \mathrm{Mes}(\mathbf{5 a}),\left(\mathrm{CH}_{3}\right)_{2} \mathrm{C}=\mathrm{NOTs}(\mathbf{5 b}), \mathrm{CH}_{3} \mathrm{ONH}_{2}(\mathbf{1 5}) \\
& \mathrm{CS} \quad=\text { DMPU, HMPA, } \mathrm{Et}_{3} \mathrm{~N}, \mathrm{TMEDA}, \mathrm{DMSO}, \mathrm{NMP}, \mathrm{PC}, \mathrm{DMEU} \text {, } \\
& \text { DMAC, Sulfolane, TMU, DMF }
\end{aligned}
$$

\section{Scheme 25}

There is a need for a copper catalyst to react organozinc chlorides and diorganozincs with oximes at room temperature. Triorganozincates can react without using any catalyst, but the yield of amine is low. ${ }^{97,98}$ All three organozinc reagents react with 5a in the presence of $\mathrm{CuCN}$, as catalyst, to give primary amines in low to moderate yields. Primary arylamines can be obtained in high yields by the use of a dipolar aprotic cosolvent (Scheme 25). ${ }^{99-101}$ Addition of a 
P-, N-, or S-donor ligand causes a significant reduction in the quantity of copper catalysts and a remarkable increase in the yield of amine (Scheme 26). ${ }^{101}$

There is no need to use a copper catalyst to obtain primary arylamines in good yields, if the amination of arylzinc reagents with acetone oxime $O$-tosylate $\mathbf{5 b}$, in the presence of a cosolvent, is performed at $40^{\circ} \mathrm{C}$.

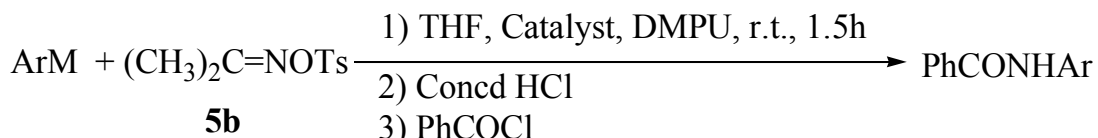

$$
\begin{aligned}
& \mathrm{M}=\mathrm{ZnCl}, 1 / 2 \mathrm{Zn}, 1 / 3 \mathrm{ZnMgBr} \\
& \text { Ar }=\mathrm{C}_{6} \mathrm{H}_{5}, 4-\mathrm{MeC}_{6} \mathrm{H}_{4}, 4-\mathrm{MeOC}_{6} \mathrm{H}_{4}, 3-\mathrm{ClC}_{6} \mathrm{H}_{4}, 4-\mathrm{MeSC}_{6} \mathrm{H}_{4} \text {, } \\
& \text { 2,5- } \mathrm{Me}_{2} \mathrm{C}_{6} \mathrm{H}_{3} \text {, 1-naphthyl } \\
& \text { Catalyst }=\mathrm{CuCN}, \mathrm{CuCl}, \mathrm{CuBr}, \mathrm{CuI}, \mathrm{CuSCN}, \mathrm{CuBr}_{2}, \mathrm{CuCl}_{2}, \mathrm{Cu}(\mathrm{SCN})_{2} \text {, } \\
& \mathrm{Cu}(\mathrm{I}) / \text { Ligand, } \mathrm{Cu}(\mathrm{II}) / \text { Ligand } \\
& \text { Ligand }=\mathrm{Me}_{2} \mathrm{~S}, \mathrm{n}-\mathrm{Bu}_{3} \mathrm{P}, \mathrm{Ph}_{3} \mathrm{~N}, \mathrm{Ph}_{3} \mathrm{P} \\
& \text { Yield, \% = 74-93 (with } \mathrm{R}_{3} \mathrm{ZnMgBr} \text { ), 74-90 (with } \mathrm{R}_{2} \mathrm{Zn} \text { ), } 62-95 \text { (with } \mathrm{RZnCl)}
\end{aligned}
$$

\section{Scheme 26}

Methylarylzinc reagents react with $\mathbf{5 a}$ in the presence of $\mathrm{CuCN}$ as catalyst to give arylamines in low to moderate yields. ${ }^{102}$

Dialkylzinc reagents react with imino esters to give the $\mathrm{N}$-alkylation product as the major product or the only product, whereas alkylzinc and benzylzinc halides react to give the carbophilic addition product. ${ }^{48,103-105}$

Diethylzinc reacts with $\alpha$-ketimino esters 16a-d in toluene at room temperature to produce Nethylation products in high yields (Scheme 27). ${ }^{105}$ However, the hindered imine ester 16e does not react with diethylzinc.

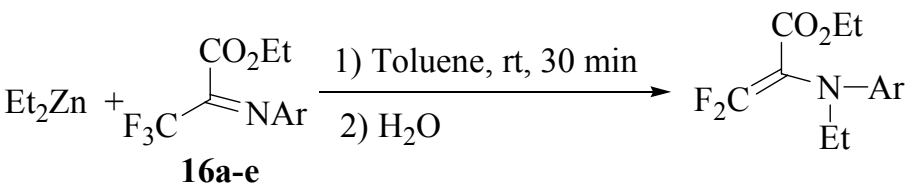

$$
\begin{aligned}
& \text { Ar } \quad=\mathrm{C}_{6} \mathrm{H}_{5}, \mathbf{1 6} \mathbf{a}, 4-\mathrm{MeOC}_{6} \mathrm{H}_{4}, \mathbf{1 6 b}, 4-\mathrm{ClC}_{6} \mathrm{H}_{4}, \mathbf{1 6 c}, 2-\mathrm{EtC}_{6} \mathrm{H}_{4}, \mathbf{1 6 d}, 2,6-\mathrm{Me}_{2} \mathrm{C}_{6} \mathrm{H}_{3}, \mathbf{1 6 e} \\
& \text { Yield, } \%=80, \quad 88, \quad 84, \quad 65, \quad 1
\end{aligned}
$$

\section{Scheme 27}

Niwa and coworkers observed that, if the reaction of diethylzinc reagent with $2-[N-(p-$ methoxyphenyl)imino]malonate 4 at $-78{ }^{\circ} \mathrm{C}$ is carried out in toluene in place of THF, the 
N-ethylation product can be prepared in higher yield ( $80 \%$ instead of $40 \%$ ). In addition the reaction is completed in a shorter time. ${ }^{49,50}$

Amination of organozinc halides, diorganozincs and lithium triorganozincates with oxaziridines have been studied by Ghoraf and Vidal. ${ }^{106}$ They found diorganozinc to be the most successful organozinc reagent. Amination reactions of diorganozincs with oxaridine 17 were conducted in $\mathrm{Et}_{2} \mathrm{O}$ :hexane $(1: 4)$ at $0{ }^{\circ} \mathrm{C}$ without using any catalyst. Only $n$-alkylzincs gave high yields of Boc-protected primary amines. Amination of sec-, tert-, and cycloalkylzinc, and arylzinc reagents resulted in low yields (Scheme 28).

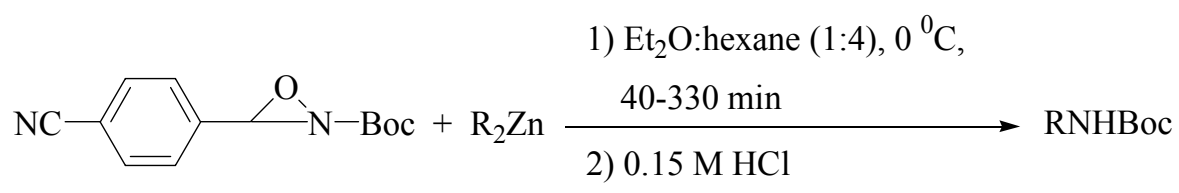

17

$\mathrm{R}=n$-Bu, $s$-Bu, $t$-Bu, $c$-hex, cis-pinane-2-ylmethyl, $\mathrm{C}_{6} \mathrm{H}_{5}, 4-\mathrm{MeOC}_{6} \mathrm{H}_{4}$

Yield, $\%=71, \quad 28, \quad 21, \quad 40, \quad 39, \quad 43, \quad 29$

\section{Scheme 28}

It is proposed that the oxygen of oxaziridine $\mathbf{1 7}$ coordinates to the zinc atom to form the zincate complex 18. This coordination facilitates attack of the organo group on the electrophilic nitrogen to open the oxaziridine ring (Scheme 29). Therefore, ethereal solvents, which can act as competing Lewis bases, must be avoided.

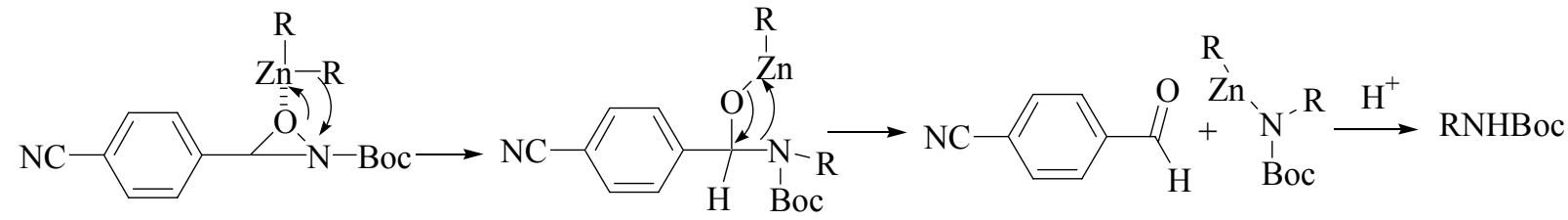

18

\section{Scheme 29}

Some attempts have been made to use diazonium salts for amination of organozinc reagents. Curtin and Ursprung reacted alkyl, benzyl and arylzinc chlorides with a suspension of aryldiazonium tetrafluoroborates in diethyl ether at $0{ }^{\circ} \mathrm{C}$ to afford the corresponding azo compounds in low yields. ${ }^{107}$ Attempts to carry out the reaction using a pyridine solution of aryldiazonium tetrafluoroborates resulted in poorer yields.

Diorganozinc reagents were found to react with benzenediazonium tetrafluoroborates in xylene-DMF (1:2) or in diethyl ether at $0{ }^{\circ} \mathrm{C}$ very fast and give azo compounds in high yields. ${ }^{108}$ 
Erdik and Koçoğlu ${ }^{109}$ revisited this amination reaction and showed that triarylzincates prepared by transmetallation of corresponding arylmagnesium reagents with $\mathrm{ZnCl}_{2}$.TMEDA react with benzenediazonium tetrafluoroborate in THF at $-15{ }^{\circ} \mathrm{C}$ to give the corresponding arylazo compounds in high yields (Scheme 30). Alkyl, cycloalkyl-, and benzylzincates were found to be unsuccessful. Arylazo compounds were subsequently reduced, using $\mathrm{NaBH}_{4} / \mathrm{NiCl}_{2} .6$ $\mathrm{H}_{2} \mathrm{O}$, and arylamines were obtained as a mixture with aniline in low to moderate yields.

$$
\begin{aligned}
& \mathrm{R}_{3} \mathrm{ZnMgBr}+\mathrm{C}_{6} \mathrm{H}_{5} \mathrm{~N}_{2} \mathrm{BF}_{4} \frac{\text { 1) } \mathrm{THF},-15^{0} \mathrm{C}, 1 \mathrm{H}}{\text { 2) } 6 \mathrm{~N} \mathrm{HCl}} \mathrm{C}_{6} \mathrm{H}_{5} \mathrm{~N}=\mathrm{NR} \\
& \mathrm{R} \quad=4-\mathrm{MeC}_{6} \mathrm{H}_{4}, 4-\mathrm{MeOC}_{6} \mathrm{H}_{4}, 4-\mathrm{BrC}_{6} \mathrm{H}_{5}, n \text {-hex, } c \text {-hex, } \mathrm{Bn} \\
& \text { Yield, } \%=87, \quad 88, \quad 72, \quad-, \quad-, \quad-
\end{aligned}
$$

\section{Scheme 30}

It is observed that triarylzincate, prepared separately, gave higher yields compared with in situ prepared triarylzincate, whereas in situ prepared arylzinc chloride was more successful than arylzinc chloride prepared separately.

Rieke and coworkers reported a procedure for the preparation of primary amines using organozinc halides and di-tert-butyl azodicarboxylate (DBAD) 19 in three steps. ${ }^{110}$ They performed the first step in high yields (Scheme 31). In this step, organozinc halide reacts with DBAD at $0{ }^{\circ} \mathrm{C}$ to afford di-tert-butylhydrazinodicarboxylates in moderate to high yields after hydrolysis with $\mathrm{NaHCO}_{3}$. In the second step, the tert-butoxycarbonyl groups can be removed with $\mathrm{CF}_{3} \mathrm{COOH}$. And finally, the primary amines can be obtained after reductive cleavage of the $\mathrm{N}-\mathrm{N}$ bond using $\mathrm{H}_{2} /$ Raney Ni.

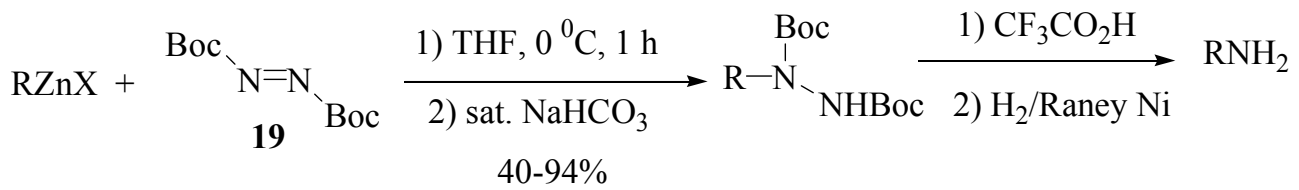

$$
\begin{aligned}
& \mathrm{R}=\text { Oct-2-yl, 5- } \mathrm{EtO}_{2} \mathrm{C} \text {-pent-1-yl, 4- } \mathrm{MeO}_{2} \mathrm{C} \text {-but-1-yl, 5-Cl-pent-1-yl, } \\
& \mathrm{Bn} \text {, tert-pentyl, 4-EtO } \mathrm{CC}_{6} \mathrm{H}_{4}, 4-\mathrm{NCC}_{6} \mathrm{H}_{4} \text {, 2-thienyl }
\end{aligned}
$$

\section{Scheme 31}

Recently, functionalized arylazotosylates have been used as aminating reagents in the preparation of secondary aryl-alkylamines by the electrophilic amination of alkylzinc halides and dialkylzinc reagents (Scheme 32). ${ }^{111}$ The cleavage of the N-N bond was performed using Raney nickel in refluxing ethanol. 


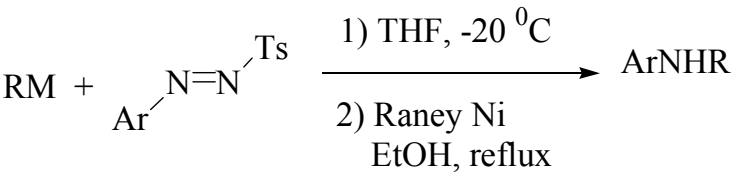

$$
\begin{aligned}
& 41-79 \% \\
& \mathrm{M}=\mathrm{ZnX}(\mathrm{X}=\mathrm{Br}, \mathrm{I}), 1 / 2 \mathrm{Zn} \\
& \mathrm{R}=c \text {-Pentyl, } c \text {-hex, } n \text {-pentyl, } n \text {-octyl, 2-EtO }{ }_{2} \mathrm{CEt} \text {, } \\
& \text { 2-norbornyl, myrtanyl } \\
& \mathrm{Ar}=4-\mathrm{EtO}_{2} \mathrm{CC}_{6} \mathrm{H}_{4}, 4-\mathrm{MeOC}_{6} \mathrm{H}_{4}, 3,5-\mathrm{Me}_{2} \mathrm{C}_{6} \mathrm{H}_{3} \text {, } \\
& 3,5-\left(\mathrm{F}_{3} \mathrm{C}\right)_{2} \mathrm{C}_{6} \mathrm{H}_{3}, 4-\mathrm{FC}_{6} \mathrm{H}_{4}, 3 \text {-quinolyl }
\end{aligned}
$$

\section{Scheme 32}

\section{Electrophilic Amination of Organocopper Reagents}

Organocopper reagents are indispensible in the field of synthetic organic chemistry. They have been used not only for the synthesis of simple organic molecules, but also for the synthesis of various types of natural products with high chemo-, regio- and stereoselectivity. ${ }^{112}$

To date, most aminating reagents, for the electrophilic amination of mono-organocopper and cuprates were based on $\mathrm{sp}^{3}$-hybridized nitrogen species. For example, $\mathrm{N}, \mathrm{N}$-dimethyl- $O$-(methylsulfonyl)hydroxylamine $\left(\mathrm{Me}_{2} \mathrm{NOSO}_{2} \mathrm{Me}\right)^{113}$ and $N, N$-dimethyl- $O$-(diphenylphosphinyl)hydroxylamine $\left(\mathrm{Me}_{2} \mathrm{NOPOPh}_{2}\right)^{37}$ were used for electrophilic amination of higher order 1alkynylcuprates, to obtain the corresponding amines in poor to high yields.

4-(Benzoyloxy)piperidine reacts with phenylcopper and diphenylcuprate to furnish aniline in good to high yields (Scheme 33). ${ }^{39}$ Diphenylcuprate gives a higher yield than phenylcopper. The organometallic precursor $(\mathrm{PhLi}, \mathrm{PhMgBr}$ or $\mathrm{PhZnCl})$ used in the preparation of organocopper reagents does not affect the yield, but using a $\mathrm{Li}_{2} \mathrm{CuCl}_{3}$ complex instead of a $\mathrm{CuBr}$. $\mathrm{SMe}_{2}$ complex as copper source leads to an increase in the yield of aniline.

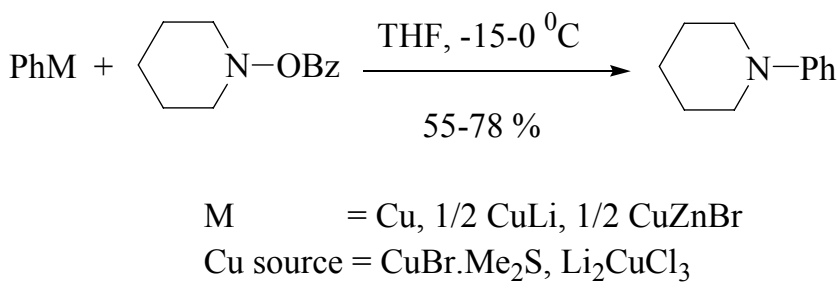

\section{Scheme 33}

Alternatively, N,O-Bis(trimethylsilyl)hydroxylamine 20, aminated higher-order cyanocuprates to give aromatic, heteroaromatic and alkyl amines in satisfactory to high yields (Scheme 
34). ${ }^{114}$ According to the proposed mechanism of Ricci et. al., in the first step of the amination reaction, one of the $\mathrm{R}$ groups in $\mathrm{R}_{2} \mathrm{CuCNLi}_{2}$ abstracts one proton from the aminating reagent to give a lower-order cyanocuprate and lithium $N$-silyl- $N$-siloxamide (nitrenoid), 21a. After the formation of 21a, depending on the type of $\mathrm{R}$ group in the lithium organylcyanocuprate, nitrenoid-oxenoid (21a-21b) equilibrium may occur. If $\mathrm{R}$ is an aryl group, lithium arylcyanocuprate reacts with $\mathbf{2 1 a}$ without allowing formation of $\mathbf{2 1} \mathbf{b}$, and gives the corresponding silylated amine (Scheme 34 path A). However, if $\mathrm{R}$ is an alkyl group, the 21a-21b equilibrium may occur, and the cyanocuprate reacts with both the nitrenoid and the oxenoid to give amine and alcohol (Scheme 34 Path B).

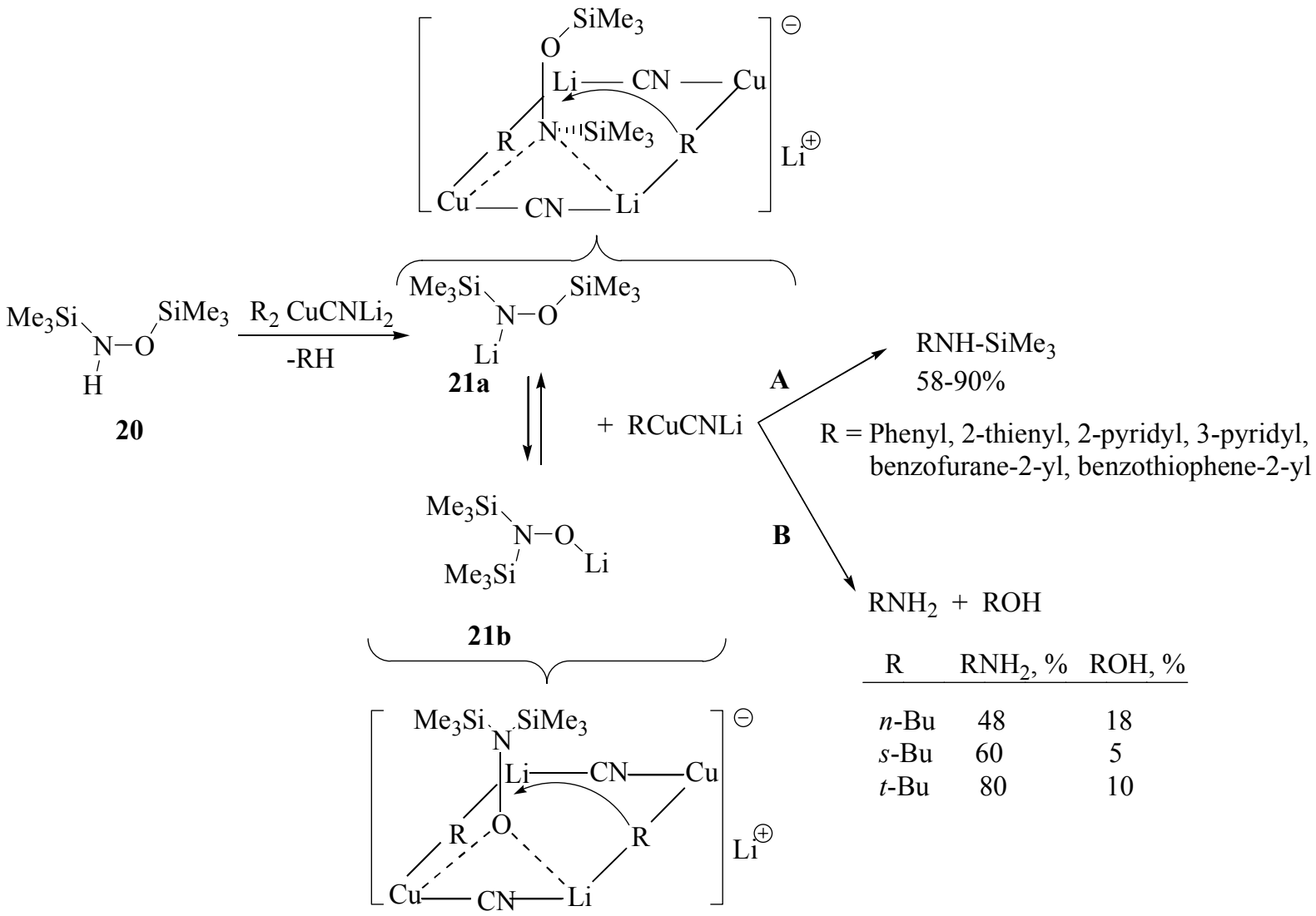

\section{Scheme 34}

Reaction of $n-\mathrm{BuPhCuCNLi}_{2}$, a mixed higher-order cyanocuprate, with $\mathbf{2 0}$ resulted in the formation of $50 \%$ of $\mathrm{PhNHSiMe}_{3}, 35 \%$ of $n-\mathrm{BuNH}_{2}$, and $5 \%$ of $n-\mathrm{BuOH} . \mathrm{Ph}_{2} \mathrm{CuLi}_{2}$ gave a slightly lower yield (80\%) compared to the corresponding cyanocuprate $(90 \%)$.

$\mathrm{N}$-Alkylarylamines and $\mathrm{N}$-alkylheteroarylamines were prepared in moderate to high yields by the electrophilic amination of higher-order cyanocuprates with $N$-alkylhydroxylamines (Scheme 35). ${ }^{115} \mathrm{~N}$-alkyl-O-trimethylsilylhydroxylamines react with higher-order cyanocuprates at room temperature, whereas $\mathbf{2 0}$ reacts at low temperatures. 


$$
\begin{aligned}
& \mathrm{Ar}_{2} \mathrm{CuCNLi}+\mathrm{RNH}-\mathrm{OSiMe}_{3} \underset{45-88 \%}{\stackrel{\mathrm{THF}, \mathrm{rt}}{\longrightarrow}} \text { Ar-NHR } \\
& \mathrm{Ar}=\mathrm{C}_{6} \mathrm{H}_{5}, 4-\mathrm{MeC}_{6} \mathrm{H}_{4}, 3-\mathrm{MeOC}_{6} \mathrm{H}_{4}, 4-\mathrm{MeOC}_{6} \mathrm{H}_{4} \text {, } \\
& \text { 4- } \mathrm{FC}_{6} \mathrm{H}_{4}, 2 \text {-pyridyl, 2-thienyl } \\
& \mathrm{R}=\mathrm{Me}, i-\mathrm{Pr}, t-\mathrm{Bu}
\end{aligned}
$$

\section{Scheme 35}

Beak and Selling ${ }^{34}$ treated phenyl and $s$-butyl cuprates with methoxylamine/methyllithium at $-15{ }^{\circ} \mathrm{C}$ and obtained $s-\mathrm{BuNH}_{2}$ and $\mathrm{PhNH}_{2}$ in 58 and $83 \%$ yields, respectively.

Genêt and co-workers ${ }^{116-119}$ have developed new electrophilic amination reagents (Scheme 36) for the direct transfer of the N-protected moiety to a nucleophilic site. These types of reagents are useful, especially when the synthesis of sensitive primary amines, which are otherwise not stable as free bases, is needed.

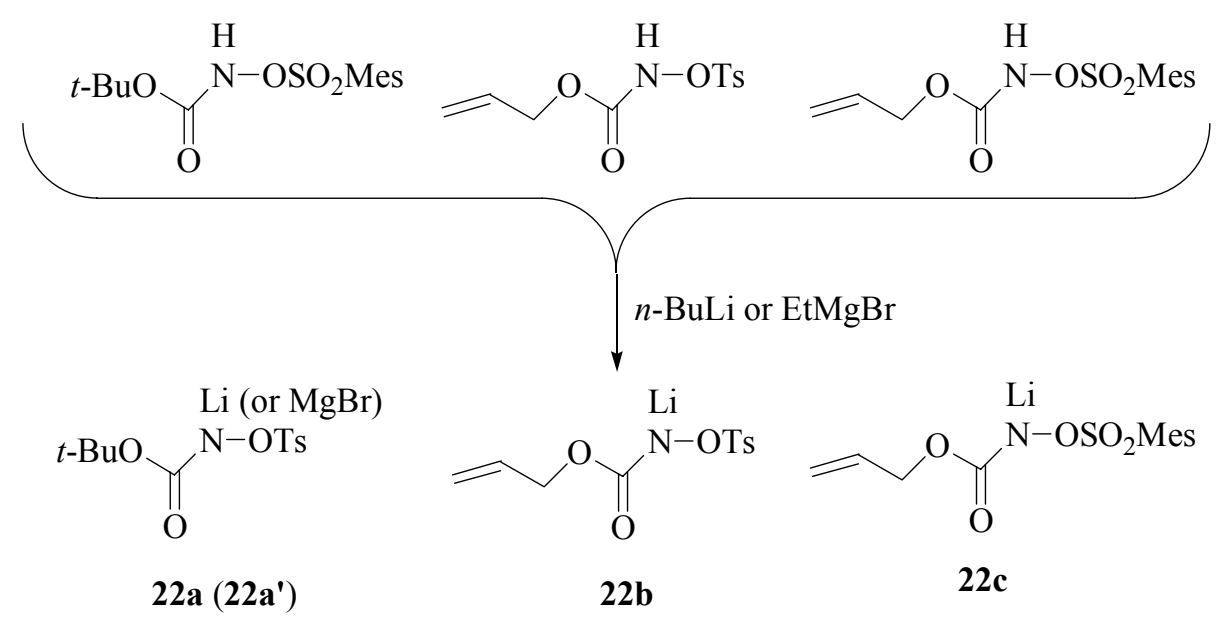

\section{Scheme 36}

These reagents were found to be suitable for the electrophilic amination of arylcopper and dialkylcuprates but not for diarylcuprates and diarylcyanocuprates (Scheme 37a). The use of $(\mathrm{MgCl}) \mathrm{BTOC}, \mathbf{2 2 a}$ ', supplied alkylamines in higher yields than that of LiBTOC 22a, in the amination of dialkylcuprates. In the case of amination of $\mathrm{PhCu}$, LiBTOC was more successful. 


$$
\begin{aligned}
& \mathrm{RM}+\underset{\mathbf{2 2 a}, \mathbf{2 2 a} \mathbf{a}^{\prime}}{\operatorname{BocN}\left(\mathrm{M}^{\prime}\right) \mathrm{OTs}} \frac{\text { 1) } \mathrm{THF},-78{ }^{0} \mathrm{C}, 1.5 \mathrm{H}}{\text { 2) aq. } \mathrm{NH}_{4} \mathrm{Cl}} \text { RNHBoc } \\
& \mathrm{M}=\mathrm{Cu}, 1 / 2 \mathrm{CuLi}, 1 / 2 \mathrm{CuMgBr} \\
& \mathrm{M}^{\prime} \quad=\mathrm{Li}(\text { 22a), } \mathrm{MgCl} \text { (22a') } \\
& \mathrm{R}=n \text {-Bu, } s \text {-Bu, 2-methyl-propen-3-yl, 4- } \mathrm{MeOC}_{6} \mathrm{H}_{4}, 4-\mathrm{FC}_{6} \mathrm{H}_{4} \text {, } \\
& \text { 2-pyridyl, 2-thienyl, 3-furanyl } \\
& \text { Yield, } \%=48-73(\mathrm{M}=\mathrm{Cu}, \mathrm{R}=\text { aryl), } 57-72(\mathrm{M}=1 / 2 \mathrm{CuMgBr} \text { (or } \mathrm{Li}) \text {, } \\
& \mathrm{R}=\text { alkyl), } 23-38\left(\mathrm{M}=1 / 2 \mathrm{CuLi} \text { or } 1 / 2 \mathrm{CuCN}(\mathrm{Li} \text { or } \mathrm{MgCl})_{2}\right)
\end{aligned}
$$

\section{Scheme 37a}

Compounds 22b and 22c allowed the preparation of alloc-protected primary arylamines in low to good yields (Scheme 37b).

$$
\begin{aligned}
& \mathrm{ArCu}+22 \mathbf{b} \text { or } 22 \mathbf{c} \frac{\text { 1) THF, }-78{ }^{0} \mathrm{C}}{\text { 2) aq. } \mathrm{NH}_{4} \mathrm{Cl}} \text { ArNHAlloc } \\
& \text { Ar }=\mathrm{C}_{6} \mathrm{H}_{5}, 4-\mathrm{MeC}_{6} \mathrm{H}_{4}, 4-\mathrm{MeOC}_{6} \mathrm{H}_{4}, 3-\mathrm{FC}_{6} \mathrm{H}_{4} \text {, } \\
& \text { 2-pyridyl, 1-naphtyl } \\
& \text { Yield, } \%=26-68 \% \text { (with 22b), 10-60\% (with 22c) }
\end{aligned}
$$

\section{Scheme 37b}

Electrophilic amination of dialkylcuprates with 22a-c was presumed to be an $\mathrm{S}_{\mathrm{N}} 2$ process in which the aminating reagent interacted with the dimeric cuprate to form an intermediate and a mechanism very similar to that proposed for the electrophilic amination of $\mathbf{2 0}$ with diarylcyanocuprates ${ }^{114}$ was suggested.

Yamamoto and Maruoka, ${ }^{120}$ described the preparation of secondary and tertiary amines based on the oxidative coupling of lithium diorganylcopper amides, which were generated from lithium dialkyl(or diaryl)cuprates and alkyl-, cycloalkyl-, benzyl-, or aryl- primary or secondary amines. Iwao and co-workers ${ }^{121}$ reported a procedure for the oxidative coupling reaction of ortholithiated benzamides with anilido-chloro or -cyano cuprates to yield substituted $N$-aryl anthranyl amides. In both studies, five equivalents of cuprate were utilized with respect to the amine and molecular oxygen as an oxidant at $-78-25^{\circ} \mathrm{C}$.

Dembech, Ricci and co-workers described the synthesis of aliphatic, aromatic, and heteroaromatic amines by oxidative coupling of lithium- and zinc-amidocyanocuprates in which one equivalent of cuprate with respect to the amine was used. ${ }^{122,123}$ A number of secondary and tertiary amines were synthesized by $\mathrm{N}$-alkylation, -vinylation, -arylation, and -heteroarylation of simple primary and secondary amines using this procedure (Scheme 38). It was observed that the preparative method of the amidocuprate did not cause any major change in the yield of products. 


$$
\begin{aligned}
& \begin{aligned}
\mathrm{R}^{1} \mathrm{Cu}(\mathrm{CN}) \mathrm{Li} \stackrel{\mathrm{R}^{2} \mathrm{R}^{3} \mathrm{NLi}}{\longrightarrow} \mathrm{R}^{1}\left(\mathrm{R}^{2} \mathrm{R}^{3}\right) \mathrm{NCu}(\mathrm{CN}) \mathrm{Li}_{2} \stackrel{\mathrm{O}_{2} / \mathrm{Cu}\left(\mathrm{NO}_{3}\right)_{2}}{\longrightarrow} \\
\mathrm{R}^{1} \mathrm{Cu}(\mathrm{CN}) \mathrm{ZnCl} \stackrel{\mathrm{R}^{2} \mathrm{R}^{3} \mathrm{NLi}}{\longrightarrow} \mathrm{R}^{1}\left(\mathrm{R}^{2} \mathrm{R}^{3}\right) \mathrm{NCu}(\mathrm{CN}) \mathrm{ZCl} \stackrel{\mathrm{O}_{2} / o-\left(\mathrm{NO}_{2}\right)_{2} \mathrm{Ph}}{\longrightarrow}
\end{aligned} \longrightarrow \mathrm{R}^{2 /} \mathrm{R}^{3}-\mathrm{R}^{1} \\
& \mathrm{R}^{1}, \mathrm{R}^{2}, \mathrm{R}^{3}=\mathrm{Bu}, \mathrm{Ph}, \mathrm{Ph} ; \mathrm{Me}, \mathrm{Ph}, \mathrm{PhCH}_{2} ; \mathrm{PhCH}=\mathrm{CH}, i-\mathrm{Pr}, i-\mathrm{Pr} ; \mathrm{Ph}, i-\mathrm{Pr}, i-\mathrm{Pr} ; \mathrm{Ph}, \mathrm{H}, \mathrm{Ph} \text {; } \\
& \mathrm{Ph}, \mathrm{Ph}, \mathrm{Ph} ; \mathrm{Ph}, \mathrm{Ph}, \mathrm{PhCH}_{2} ; \text { 2-thienyl,Me,Ph; 2-benzofuryl,Me, } \mathrm{Ph}
\end{aligned}
$$

\section{Scheme 38}

Zinc-amidocyanocuprate was found to give higher yields than lithium-amidocyanocuprate. Oxidation of zinc-amidocuprates and lithium-amidocuprates with $\mathrm{O}_{2} / o$-dinitrobenzene and $\mathrm{O}_{2}$ / $\mathrm{Cu}\left(\mathrm{NO}_{3}\right)_{2}$, respectively, in place of $\mathrm{O}_{2}$ alone, afforded higher yields.

Functional groups bearing primary, secondary, and tertiary amines were prepared by the oxidative coupling of polyfunctional aryl and heteroaryl amidocuprates (Scheme 39). ${ }^{124,125}$ Amidocuprates were prepared by treatment of arylcopper reagents, prepared by transmetallation of functionalized arylmagnesium reagents and $\mathrm{CuCl}_{2} \cdot \mathrm{LiCl}$, with lithium amides at $-50{ }^{\circ} \mathrm{C}$ for $2 \mathrm{~h}$. Subsequent oxidation with 2,3,5,6-tetrachloro-1,4-benzoquinone (chloranil) at -78 to $-50{ }^{\circ} \mathrm{C}$ with stirring for $12 \mathrm{~h}$ afforded, after purification, the desired amines.

$$
\begin{aligned}
& \operatorname{ArMgCl} . \mathrm{LiCl} \underset{\left.\mathrm{Et}_{2} \mathrm{NCH}_{2} \mathrm{CH}_{2}\right)_{2} \mathrm{O},-50{ }^{0} \mathrm{C},}{\stackrel{\mathrm{THF}, \mathrm{CuCl} .2 \mathrm{LiCl}}{\longrightarrow}} \operatorname{ArCu} . \mathrm{LiCl} \frac{1) \mathrm{R}^{1} \mathrm{R}^{2} \mathrm{NLi},-50{ }^{0} \mathrm{C}, 1.5 \mathrm{~h}}{\text { 2) Chloranil, }-78{ }^{0} \mathrm{C}, 12 \mathrm{~h}} \mathrm{Ar}-\mathrm{N}_{\mathrm{R}^{\prime}} \mathrm{R}^{1} \\
& 45 \mathrm{~min} \\
& \text { Ar } \quad=\mathrm{C}_{6} \mathrm{H}_{5}, 4-\mathrm{FGC}_{6} \mathrm{H}_{4}\left(\mathrm{FG}=\mathrm{CN}, 4-\mathrm{EtO}_{2} \mathrm{C}, 4-\mathrm{MeO}, \mathrm{I}, \mathrm{Br}, \mathrm{Me}, 1 \text {-pyrrolidin-1-yl-ethanon }\right) \text {, } \\
& 2-\mathrm{O}_{2} \mathrm{NC}_{6} \mathrm{H}_{4}, 2,5-\left(\mathrm{CF}_{3}\right)_{2} \mathrm{C}_{6} \mathrm{H}_{3}, 3-\mathrm{IC}_{6} \mathrm{H}_{4}, 2-\mathrm{Cl}-5-\mathrm{F}_{3} \mathrm{CC}_{6} \mathrm{H}_{3}, 3,5-(\mathrm{Boc})_{2}-2-\mathrm{EtO}_{2} \mathrm{CC}_{6} \mathrm{H}_{2} \text {, } \\
& \text { 2,6-(Boc) } \left.)_{2}-4-\mathrm{EtO}_{2} \mathrm{C} \text {-3-pyridyl, 3,5-(Br) }\right)_{2} \text {-2-pyridyl, 2-benzo [b] thienyl, 2-benzothiazyl } \\
& \mathrm{R}^{1} \mathrm{R}^{2} \mathrm{NLi}=\left(\mathrm{SiMe}_{3}\right)_{2} \mathrm{NLi}, 4-\mathrm{ClC}_{6} \mathrm{H}_{4}(\mathrm{TBS}) \mathrm{NLi}, 2,4-\mathrm{Me}_{2} \mathrm{C}_{6} \mathrm{H}_{3} \mathrm{~N}(\mathrm{TBS}) \mathrm{Li}, 4-\mathrm{EtO}_{2} \mathrm{CC}_{6} \mathrm{H}_{4} \mathrm{~N}(\mathrm{TBS}) \mathrm{Li} \text {, } \\
& \text { 4- } \mathrm{MeOC}_{6} \mathrm{H}_{4} \mathrm{~N}(\mathrm{TBS}) \mathrm{Li},\left(4-\mathrm{NCC}_{6} \mathrm{H}_{4}\right)\left(4-\mathrm{EtO}_{2} \mathrm{CC}_{6} \mathrm{H}_{4}\right) \mathrm{NLi},\left(4-\mathrm{EtO}_{2} \mathrm{CC}_{6} \mathrm{H}_{4}\right)\left(4-\mathrm{BrC}_{6} \mathrm{H}_{4}\right) \mathrm{NLi} \text {, } \\
& \text { (2,3-dihydro- } 1 H \text {-indolyl)Li }
\end{aligned}
$$

\section{Scheme 39}

Chloranil was proposed to coordinate to the copper center of the amidocuprate as shown in Scheme 40 during oxidation of the lithium amidocuprate. 


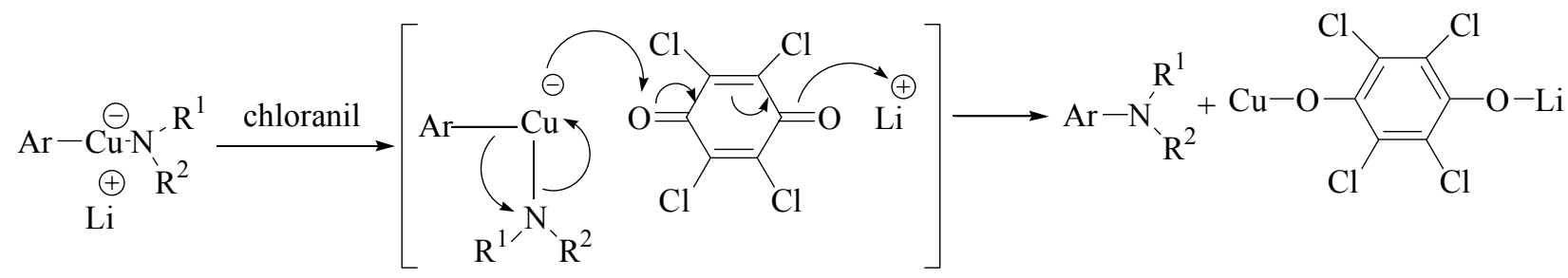

\section{Scheme 40}

Iodophenyldiacetate $\left(\mathrm{PhI}(\mathrm{OAc})_{2}\right)$ was used as the oxidizing reagent for amidocuprates obtained from heteroaromatic zinc reagents and the corresponding primary, secondary and tertiary amines were formed in good to high yields (Scheme 41). ${ }^{126}$

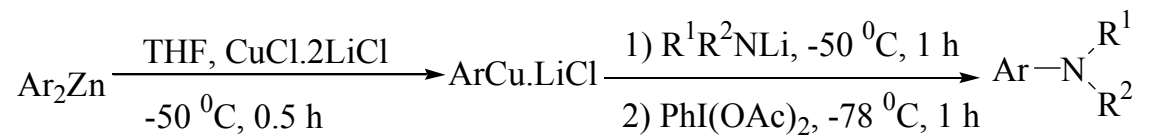

$$
\begin{aligned}
& \text { Ar = 2,4-dibromo-5-thiazolyl, 2-bromo-5-thiazolyl, 2-bromo-5-TMS-4-thiazolyl, } \\
& \text { 2-phenylsulfanyl-5-thiazolyl, 2-benzothiazyl, 2,4-dibromo-3-thienyl, } \\
& \text { 1,3,5-trimethyl-1 } H \text {-4-pyrazolyl, 3,5-dimethyl-4-isoxazolyl, 2-benzofuryl, } \\
& \text { 3-methyl-1-phenyl-1H-5-pyrazolyl } \\
& \mathrm{R}^{1} \mathrm{R}^{2} \mathrm{NLi}=\left(\mathrm{SiMe}_{3}\right)_{2} \mathrm{NLi} \text {, (4-morpholinyl)Li, (4-methyl-1-piperazinyl)Li, }(n-\mathrm{Pr})_{2} \mathrm{NLi} \text {, } \\
& \mathrm{Ph}_{2} \mathrm{NLi}, \mathrm{Ph} \text { (TBS)NLi, (2,2,6,6-tetramethyl-1-piperidinyl)Li }
\end{aligned}
$$

\section{Scheme 41}

Amination of lithium cuprates with benzenediazonium tetrafluoroborate at $-78{ }^{\circ} \mathrm{C}$ resulted in low yields. ${ }^{81,127}$

Phenylcopper, lower- and higher-order homocuprates, and lower- and higher-order heterocuprates react with 5a to give aniline in low to moderate yields, at room temperature after $3 \mathrm{~h}$ (Scheme 42). ${ }^{98}$

$$
\begin{aligned}
& \mathrm{PhM}+\left(\mathrm{CH}_{3}\right)_{2} \mathrm{C}=\mathrm{NOSO}_{2} \mathrm{Mes} \stackrel{\mathrm{Et}_{2} \mathrm{O} \text { or THF, } \mathrm{rt}, 3 \mathrm{~h}}{\longrightarrow}\left[\left(\mathrm{CH}_{3}\right)_{2} \mathrm{C}=\mathrm{NAr}\right] \stackrel{\text { conc. } \mathrm{HCl}}{\longrightarrow} \mathrm{PhNH}_{2} \\
& 5 a \\
& \mathrm{M}=\mathrm{Cu}, 1 / 2 \mathrm{CuLi}, 1 / 3 \mathrm{CuLi}_{2}, 1 / 2 \mathrm{Cu}(\mathrm{CN}) \mathrm{Li}_{2}, 1 / 2 \mathrm{CuZnCl}, \mathrm{Cu}(\mathrm{CN}) \mathrm{ZnCl} \\
& \mathrm{PhNH}_{2}, \%=56 \quad 43 \quad 39 \quad 35 \quad 44 \quad 56
\end{aligned}
$$

\section{Scheme 42}


Narasaka and co-workers prepared primary alkylamines by coordinating solvent prompted electrophilic amination of alkylcopper reagents with $O$-methylsulfonyloxime 6 a at low temperatures (Scheme 43). ${ }^{61,62}$ Unfortunately, lithium dialkylcupates gave low yields.

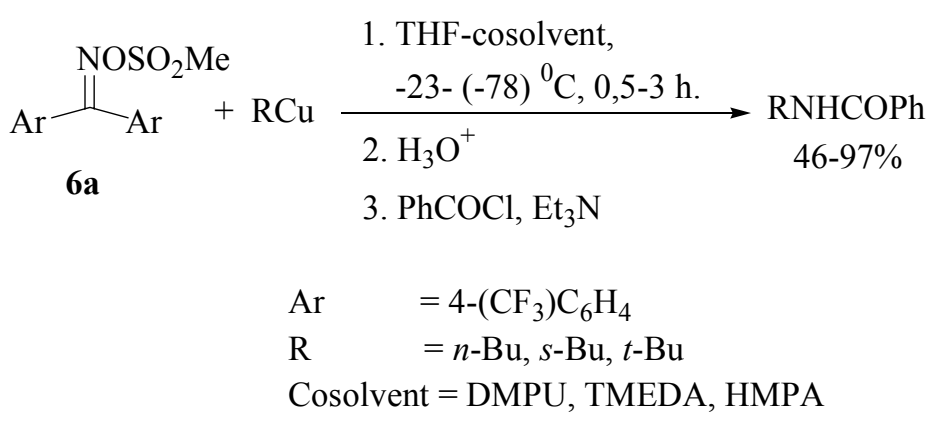

\section{Scheme 43}

\section{Electrophilic Amination of Organolithium Reagents}

Amination of organolithium reagents with haloamines is a low yielding reaction. Reaction of phenyl- and $n$-butyllithium reagents with monochloroamine, $\mathrm{H}_{2} \mathrm{NCl}$, in diethyl ether at $-50{ }^{\circ} \mathrm{C}$ give aniline and $n$-butylamine in 33 and $39 \%$ yields, respectively. ${ }^{21}$ If it is reacted with monochlorodiethylamine $\left(\mathrm{ClN}\left(\mathrm{C}_{2} \mathrm{H}_{5}\right)_{2}\right)$ lithium phenylacetylide affords the corresponding tertiary amine in only $3 \%$ yield. ${ }^{25}$

Methoxyamine $\mathbf{1 5}$ has been widely used for the amination of organolithium reagents. ${ }^{31,128-131}$ Since organolithiums may react with both protons of $\mathbf{1 5},{ }^{132}$ three equivalents of organolithium, per equivalent of methoxyamine, are used in the reactions. This difficulty can be overcome by treatment of 15 with two equivalents of methyllithium at $-78{ }^{\circ} \mathrm{C}$ to form lithium methoxyamide before use. In this way one equivalent of organolithium to be aminated is sufficient and organolithiums can be aminated in higher yields (Scheme 44). ${ }^{33,34}$ Amination of organolithiums with alkoxyamines bearing at least one proton on nitrogen can be performed in higher yields using this method. ${ }^{133}$

$$
\begin{aligned}
& \mathrm{RLi}+\mathrm{LiNHOCH}_{3} \underset{\text { 2) } \mathrm{PhCOCl}}{\stackrel{2}{ } \mathrm{O},-15{ }^{0} \mathrm{C}, 2 \mathrm{~h}} \mathrm{RNHCOR} \\
& \mathrm{R}=\mathrm{C}_{6} \mathrm{H}_{5}, 4-\mathrm{MeC}_{6} \mathrm{H}_{4}, 2-\mathrm{MeOC}_{6} \mathrm{H}_{4}, 3-\mathrm{MeOC}_{6} \mathrm{H}_{4}, 4-\mathrm{MeOC}_{6} \mathrm{H}_{4}, s-\mathrm{Bu} \\
& \mathrm{RNHCOPh}=91, \quad 93, \quad 98, \quad 73, \quad 28, \quad 68
\end{aligned}
$$

\section{Scheme 44}


The mechanism of the amination reaction of alkoxyamines with organometallic reagents, which is presumed to be as a $\mathrm{S}_{\mathrm{N}} 2$ process, has been investigated by several groups. ${ }^{134-143}$

Genêt and co-workers aminated aryl, primary and secondary alkyllithiums using lithium $t$ butyl- $N$-tosyloxycarbamate (LiBTOC), 21a, to synthesize primary amines in their $N$-Boc protected form (Scheme 45). ${ }^{116,117,119}$ LiBTOC 21a reacts with organolithium reagents according to the mechanism proposed by Beak and coworkers. ${ }^{134}$

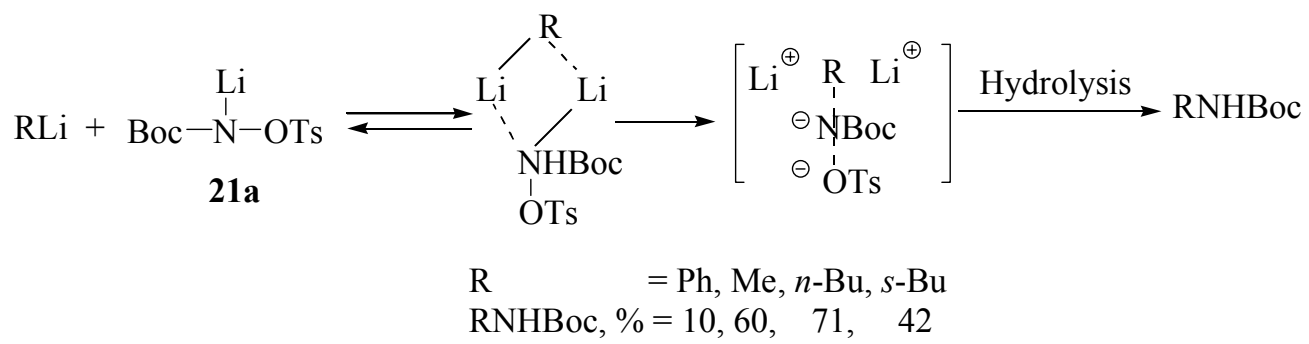

\section{Scheme 45}

Several $N, N$-dialkyl-O-(arylsulfony1)hydroxylamine derivatives were used in the electrophilic amination of alkyl-, alkenyl-, and aryllithiums at low temperatures. ${ }^{144,113}$ Reaction of 1-alkynyllithiums with $\mathrm{N}, \mathrm{N}$-dimethyl-O-(methylsulfonyl)hydroxylamine $\left(\mathrm{Me}_{2} \mathrm{NOSO}_{2} \mathrm{Me}\right)$ was unsuccessful. ${ }^{37}$ However, $O$-(diphenylphosphinyl)hydroxylamine aminated organolithiums in moderate to good yields. ${ }^{37,41}$ Attempts to aminate phenyllithium with $N, N$-diethyl- $O$ mesityloylhydroxylamine resulted in low yields; the highest yield obtained was $50 \%$ at $-30{ }^{\circ} \mathrm{C}$.

Organolithium reagents react with azides in the same way as organomagnesium reagents to give 1,3-disubstituted triazenes. $p$-Toluenesulfonyl azide was used for introducing amino groups into ortho-lithiated aromatic compounds. ${ }^{145-147}$ Aryl- and heteroaryllithiums reacted with vinyl azides to give the corresponding aromatic amines in moderate to good yields after an acidic hydrolysis. ${ }^{148}$ Allyl azide was found to be a useful reagent for the conversion of phenyllithium to aniline (61\%) using hexane as the solvent. ${ }^{76}$

Organolithiums cannot be aminated with (phenylthio)methyl azide without using $\mathrm{MgBr}_{2}$ because of the lower Lewis acidity of lithium salts. ${ }^{73}$ It was reported that the reaction of (trimethylsilyl)methyl azide with aryllithiums in diethyl ether, followed by hydrolysis, generated the corresponding aromatic amines in poor yields (35-41\%). ${ }^{149}$ Diphenyl phosphorazidate reacts easily with aryl- and heteroaryllithiums to give the corresponding amino compounds after reduction of triazene formed with sodium bis(2-methoxyethoxy)aluminum hydride. ${ }^{150}$

\section{Conclusions}

Electrophilic amination of organometallic reagents is an important and useful synthetic method for the preparation of aliphatic, aromatic and heteroaromatic amines and is continuing to gain the 
attentions of chemists. Publications on the results of our own investigations of the electrophilic aminations of organomagnesiums, mono-organocoppers, homocuprates and heterocuprates with ketoximes are in preparation.

\section{Acknowledgement}

The author would like to thank the Ankara University Research Fund (BAP) for supporting his research on electrophilic amination.

\section{References}

1. Hayes, K. S. Appl. Catal. A 2001, 187.

2. Czarnik, A. W. Acc. Chem. Res. 1996, 29, 112.

3. MacDiarmid, A. G. Synth. Met. 1997, 84, 27.

4. Gospodinova, N.; Terlemezyan, L. Prog. Polym. Sci. 1998, 23, 1443.

5. Law, K. Y. Chem. Rev. 1993, 93, 449.

6. Ricci, A. (Editor) Amino Group Chemistry: From Synthesis to the Life Sciences; WileyVCH Verlag GmbH and Co. KGaA, Weinheim, 2008.

7. Ley, S. V.; Thomas, A.M. Angew. Chem. Int. Edn. 2003, 42, 5400.

8. Mitsunobu, O. Comprehensive Organic Synthesis (Eds.: Trost, B. M.; Fleming, I.; Winterfeldt, E.), Vol. 6. Pergamon: Oxford, 1991, p. 65.

9. Hottori, T.; Sakamoto, J.; Hayashizaka, N.; Miyano, S. Synthesis 1994, 199.

10. Kienle, M.; Dubbaka, S. R.; Brada, K.; Knochel, P. Eur. J. Org. Chem., 2007, 25, 4166.

11. Semmelhack, M. F.; Rhee, H. Tetrahedron Lett. 1993, 34, 1395.

12. Erdik, E.; Ay, M. Chem. Rev. 1989, 89, 1947.

13. Mulzer, J.; Altenbach, H. J.; Brown, M.; Krohn, K.; Reissi, H. U. Organic Synthesis Highlights. VCH: Weinhim, 1991, p. 45.

14. Boche, G. Houben-Weyl, Methods of Organic Chemistry (Eds.: Heimchen, G.; Hoffman, R. W.; Mulzer, J.; E. Schaumann), Vol. E21e. Thieme: Stuttgart, 1995, p. 5153.

15. Ricci, A. Modern Amination Methods.Wiley-VCH: Weinheim, 2000.

16. Ciganek, E. Organic Reactions,(Editor: Denmark, S. E.) Vol. 72, John Wiley \& Sons, Inc., 2009, p. 1.

17. 17. Coleman, G. H.; Hauser, C. R. J. Am. Chem. Soc. 1928, 50, 1193.

18. Coleman, G. H.; Yager, C. B. J. Am. Chem. Soc. 1929, 51, 567.

19. Coleman, G. H.; Yager, C. B.; Soroos, H. J. Am. Chem. Soc. 1934, 56, 965.

20. Coleman, G. H.; Buchanan, M. A.; Paxson, W. L. J. Am. Chem. Soc. 1933, 55, 3669.

21. Coleman, G. H.; Hermanson, J. L.; Johnson, H. L. J. Am. Chem. Soc. 1937, 59, 1896.

22. Coleman, G. H.; Blomquist, R. F. J. Am. Chem. Soc. 1941, 63, 1692. 
23. Klages, F.; Nober, G.; Kircher, F.; Bock, M. Justus Liebigs Ann. Chem. 1941, 547, 1.

24. Coleman, G. H. J. Am. Chem. Soc. 1933, 55, 3001.

25. Wolf, V.; Kowitz, F. Justus Liebigs Ann. Chem. 1960, 638, 33.

26. Sinha, P.; Knochel, P. Synlett 2006, 19, 3304.

27. Hatakeyama, T.; Yoshimoto, Y.; Ghorai, S. K.; Nakamura, M. Org. Lett. 2010, 12, 1516.

28. Schverdina, N. I.; Kotscheschkow, Z. J. Gen. Chem. USSR (Engl. Transl.) 1938, 8, 1825; Chemisches Zentralblatt 1940, I, 360.

29. Schverdina, N. I.; Kotscheschkow, Z. Chemisches Zentralblatt 1942, I, 1872.

30. Brown, R.; Jones, W. G. J. Chem. Soc. 1946, 781.,

31. Gilman, H.; Avakian, S. J. Am. Chem. Soc. 1946, 68, 580.

32. Silver, M.; Shafer, P. R.; Nordlander, J. E.; Ruchardt, C.; Roberts, J. A. J. Am. Chem. Soc. 1960, 82, 2646.

33. Beak, P.; Basha, A.; Kokko, B. J. Am. Chem. Soc. 1982, 47, 2822.

34. Beak, P.; Selling, G. W. J. Org. Chem. 1989, 54, 5574.

35. Bumgardner, C. L.; Lilly, R. L. Chem. Ind. (London) 1962, 559.

36. Barton, D. H. R.; Bould, L.; Clive, D. L. J.; Magnus, P. D.; Hose, T. J. Chem. Soc., Chem. Commun. 1971, 2204.

37. Boche, G.; Bernheim, M.; Niedner, M. Angew. Chem., Int. Ed. Engl. 1983, 22, 53.

38. Erdik, E.; Ateş, S. Synth. Commun. 2006, 36, 2813.

39. Campbell, M. J.; Johnson, J. S. Org. Lett. 2007, 9, 1521.

40. Colvin, E. W.; Kirby, G. W.; Wilson, A. C. Tetrahedron Lett. 1982, 23, 3835.

41. Boche, G.; Bernheim, M.; Schrott, W. S. Tetrahedron Lett. 1982, 23, 5399.

42. Dickstein, J. S.; Kozlowski, M. C. Chem. Soc. Rev. 2008, 37, 1166.

43. Fiaud, J. C.; Kagan, H. B. Tetrahedron Lett. 1970, 1813.,

44. Fiaud, J. C.; Kagan, H. B. Tetrahedron Lett. 1971, 1019.

45. Yamamoto, Y.; Ito, W.; Maruyama, K. J. Chem. Soc., Chem. Commun., 1985, 1131.

46. Yamamoto, Y.; Nishii, S.; Maruyama, K.; Komatsu, K.; Ito, W. J. Am. Chem. Soc. 1986, $108,7778$.

47. Yamamoto, Y.; Ito, W. Tetrahedron, 1988, 44, 5415.

48. Chiev, K. P.; Roland, S.; Mangeney, P. Tetrahedron: Asymmetry 2002, 13, 2205.

49. Niwa, Y.; Takayama, K.; Shimizu, M. Tetrahedron Lett. 2001, 42, 5473,

50. Niwa, Y.; Takayama, K.; Shimizu, M. Bull Chem. Soc. Jpn.. 2002, 75, 1819.

51. Richey, H. G.; McLane, R. C.; Phillips, C. J. Tetrahedron Lett. 1976, 233.

52. Itauno, S.; Miyanaki, K.; Ito, K. Tetrahedron Lett. 1986, 27, 3033.

53. Hagopian, R. A.; Therien, M. J.; Murdoch, J. R. J. Am. Chem. Soc. 1984, 106, 5753.

54. Chaabouni, R.; Laurent, A. Bull. Soc. Chim. Fr. 1973, 2680.

55. Alvernhe, G.; Laurent, A. Tetrahedron Lett. 1972, 1007.

56. Hattori, K.; Maruoka, M.; Yamamoto, H. Tetrahedron Lett. 1982, 23, 3395.

57. Maruoka, K.; Yamamoto, H. Angew. Chem., Int. Ed. Engl. 1985, 24, 668. 
58. Erdik, E.; Ay, M. Synth. React. Inorg. Met-Org. Chem.( Synth. React. Inorg. Met-Org. Chem. Nano-met. Chem.) 1989, 19, 663,

59. Ay, M. Ph. D. Thesis, Ankara University Science Faculty, 1989.

60. Erdik, E.; Daskapan, T. Tetrahedron Lett. 2002, 43, 6237.

61. Tsutsui, H.; Hayashi, Y.; Narasaka, K. Chem. Lett. 1997, 317.

62. Tsutsui, H.; Ichikawa, T.; Narasaka, K. Bull. Chem. Soc. Jpn. 1999, 72, 1869.

63. Narasaka, K. Pure Appl. Chem. 2002, 74), 143.

64. Kitamura, M.; Chiba, S.; Narasaka, K. Bull. Chem. Soc. Jpn. 2003, 76, 1063.

65. Kitamura, M.; Suga, T.; Chiba, S.; Narasaka, K. Org. Lett. 2004, 6, 4619.

66. Boyer, J. H.; Canter, F. C. Chem. Rev. 1954,54, 1.

67. Campbell, T. W.; Day, B. F. Chem. Rev. 1951, 48, 299.

68. Scriven, E. F. V.; Turnbull, K. Chem. Rev. 1988, 88, 298.

69. Sieh, D. H.; Wilbur, D. J.; Michejda, C. J. J. Am. Chem. Soc. 1980, 102, 3883.

70. Smith, P. S.; Rowe, C. D.; Bruner, L. B. J. Org. Chem. 1969, 34, 3430.

71. Nishiyama, K.; Tanaka, N. J. Chem. Soc., Chem. Commun. 1983, 1322.

72. Wiber N.; Joo, W. C. J. Organomet. Chem. 1970, 22, 333.

73. Trost, B. M.; Pearson, W. H. J. Am. Chem. Soc. 1981, 103, 2483.

74. Trost, B. M.; Pearson, W. H. J. Am. Chem. Soc. 1983, 105, 1054.

75. Reeves, W. P.; Bahr, M. L. Synthesis 1976, 823.

76. Kabalka, G. W.; Li, G. Tetrahedron Lett. 1997, 38, 5777.

77. Kumar, H.M.S.; Reddy, B.V.S.; Anjaneyulu, S.; Yadav, J.S. Tetrahedron Lett. 1999, 40, 8305.

78. Nomura, Y.; Anzai, H. Bull. Chem. Soc. Jpn. 1962, 35, 111.

79. Nomura, Y.; Hiroyuki, A.; Ryokichi, T.; Shioimi, K. Bull. Chem. Soc. Jpn. 1964, 37, 967

80. Nomura, Y.;H iroyuki, A. Bull. Chem. Soc. Jpn. 1964, 37, 970.

81. Garst, M. E.; Lukton, D. Synth. Commun. 1980, 10, 155.

82. Sapountzis, I.; Knochel, P. Angew. Chem. Int. Ed. 2004, 43, 897.

83. Sapountzis, I.; Knochel, P. J. Am. Chem. Soc. 2002, 124, 9390.

84. Dohle, W.; Staubitz, A.; Knochel, P. Chem. Eur. J. 2003, 9, 5323.

85. Kopp, F.; Sapountzis, I.; Knochel, P. Synlett 2003, 885.

86. Erdik, E. Organozinc Reagents in Organic Synthesis. CRC Press: New York, 1996.

87. P. Knochel, P.; Jones, P. (Eds), Organozinc Reagents: A Practical Approach. Oxford University Press: Oxford, 1999.

88. Z. Rappoport, I. Marek (Eds), Patai's The Chemistry of OrganozincCompounds, WileyVCH: Chichester, 2008.

89. Knochel, P.; R. D. Singer, R. D. Chem. Rev. 1993, 93, 2117.

90. Coleman, G. H.; Anderson, H. P.; Hermanson, J. L. J. Am. Chem. Soc. 1934, 56, 1381.

91. Barker, T., J.; Jarvo, E., R. J. Am. Chem. Soc. 2009, 131, 15598.

92. Berman, A. M.; Johnson, J. S. J. Am. Chem. Soc. 2004, 126, 5680.

93. Berman, A. M.; Johnson, J. S. J. Org. Chem. 2005, 70, 364. 
94. Berman, A. M.; Johnson, J. S. J. Org. Chem. 2006, 71, 219.

95. Berman, A. M.; Johnson, J. S. Synlett 2005, 11, 1799.

96. Berman, A. M.; Johnson, J. S. Org. Synth. 2006, 83, 31.

97. Erdik, E.; Daşkapan, T. Synth. Commun. 1999, 29, 3989.

98. Erdik E.; Daşkapan T. J. Chem. Soc., Perkin Trans. 1, 1999, 3139.

99. Daşkapan, T.; Yeşilbağ, F.; Koca, S. Appl. Organomet. Chem. 2009, 23, 213.

100. Daşkapan, T. Tetrahedron Lett. 2006, 47, 2879.

101. Daşkapan, T.; Koca, S. Appl. Organomet. Chem. 2010, 24, 12.

102. Erdik, E.; Ömür Pekel, Ö.; Kalkan, M. Appl. Organomet. Chem. 2009, 23, 245.

103. Yamamato, Y.; Ito, W.; Maruyama, K. J. Chem. Soc., Chem. Commun. 1985, 1131.

104. Courtois, G.; Miginiac, L. J. Organomet. Chem. 1989, 376, 235.

105. Uneyama, K.; Yan, P.; Hirama, S.; Katagiri, T. Tetrahedron Lett. 1996, 37, 2045.

106. Ghoraf, M.; Vidal, J. Tetrahedron Lett. 2008, 49, 7383.

107. Curtin, D. Y.; Ursprung, J. A. J. Org. Chem. 1956, 21, 1221.

108. Curtin, D. Y.; Tveten, J. L. J. Org. Chem. 1961, 26, 1764.

109. Erdik, E.; Koçoğlu, M. Main Group Metal Chem. 2002, 25, 621.

110. Velarde-Ortiz, R.; Guijarro, A.; Rieke, R. D. Tetrahedron Lett. 1998, 39, 9157.

111. Sinha, P.; Kofink, C. C.; Knochel, P. Org. Lett. 2006. 8, 3741.

112. Krause, N. Modern Organocopper Chemistry, Wiley-VCH, Weinheim, 2002

113. Bernheim, M.; Boche, G. Angew. Chem., Int. Ed. Engl. 1980, 19, 1010.

114. Casarini, A.; Dembech, P.; Lazzari, D.; Marini, E.; Reginato, G.; Ricci, A.; Seconi, G. J.Org. Chem. 1993, 58, 5620.

115. Bernardi, P.; Dembech, P.; Fabbari, G.; Ricci, A.; Seconi, G. J. Org. Chem. 1999, 64, 641.

116. Genêt, J.-P.; Mallart, S.; Greck, C.; Piveteau, E. Tetrahedron Lett. 1991, 32, 2359.

117. Greck, C.; Bischoff, L.; Girard, A.; Hajicek, J.; Genêt, J.-P. Bull. Soc. Chim. Fr. 1994, $131,429$.

118. Greck, C.; Bischoff, L.; Ferreira, F.; Genêt, J.-P. J. Org. Chem. 1995, 60, 7010.,

119. Greck, G.; Genêt, J.-P. Synlett 1997, 741.

120. Yamamoto, H.; Maruoka, K. J. Org. Chem. 1980, 45, 2739.

121. Iwao, M.; Reed, J. N.; Snieckus, V. J. Am. Chem. Soc. 1982, 104, 5531.

122. Alberti, A.; Canè, F.; Dembech, P.; Lazzari, D.; Ricci, A.; Seconi, G. J. Org. Chem. 1996, 61, 1677.

123. Canè, F.; Brancaleoni, D.; Dembech, P.; Ricci, A.; Seconi, G. Synthesis 1997, 545.

124. del Amo, V.; Dubbaka, S. R.; Krasovskiy, A.; Knochel, P. Angew. Chem. Int. Ed. 2006, 45,7838 .

125. Kienle, M.; Dubbaka, S. R.; del Amo, V.; Knochel, P. Synthesis 2007, 8, 1272.

126. Kienle, M.; Dunst, C.; Knochel, P. Org. Lett. 2009, 11, 5158.

127. Gillis, B. T.; Hagarty, J. D. J. Am. Chem. Soc. 1965,87,4576.

128. Gilman, H.; Ingham, R. K. J. Am. Chem. Soc. 1953, 75, 4843. 
129. Gilman, H.; Swayanpati, D. J. Am. Chem. Soc. 1955, 77, 5944.

130. Gilman, H.; Swayanpati, D. J. Am. Chem. Soc. 1957, 79, 208.

131. Acton, E.; Silverstein, R. J. Org. Chem. 1959, 24, 1487.

132. Erdik, E. Commun. Fac. Sci. Uniu. Ankara Ser. B 1980, 26, 83; Chem. Abstr. 1981, 95,115634p.

133. Beak, P.; Basha, A.; Kokko, B. Tetrahedron Lett. 1983, 24, 561.

134. Beak, P.; Basha, A.; Kokko, B.; Loo, D. J. Am. Chem. Soc. 1986, 108, 6016.

135. Beak, P.; Basha, A.; Kokko, B. J. Am. Chem. Soc. 1984, 106, 1511.

136. Boche, G.; Wagner, H. U. J. Chem. Soc., Chem. Commun. 1984, 1591.

137. Armstrong, D. R.; Snaith, R.; Walker, G. T. J. Chem. Soc., Chem. Commun. 1985,789.

138. McKee, M. L. J. Am. Chem. Soc. 1985, 107,859.

139. Beak, P.; Li, J. J. Am. Chem. Soc. 1991, 113, 2796.

140. Glukhovtsev, M. N.; Pross, A.; Radom, L. J. Am. Chem. Soc. 1995, 117, 9012.

141. Beak, P.; Conser Basu, K.; Li, J. J. J. Org. Chem. 1999, 64, 5218.

142. Boche, G.; Lohrenz, J. C. W. Chem. Rev. 2001, 101, 697.

143. Erdik, E.; Eroglu, F.; Kahya, D. J. Phys. Org. Chem. 2005, 18, 950.

144. Boche, G.; Mayer, N.; Bernheim, M.; Wagner, K. Angew. Chem., Int. Ed. Engl. 1978, 17, 687.

145. Narasimhan, N. S. Ammanamanchi, R. A. Tetrahedron Lett. 1983, 24, 4733.

146. Reed, J. N.; Snieckus, V. Tetrahedron Lett. 1983, 24, 3795.

147. Reed, J. N.; Snieckus, V. Tetrahedron Lett. 1984, 25, 5505.

148. Kelly, T. R.; Maguire, M. P. Tetrahedron 1985, 41, 3033.

149. Nishyama, K.; Tanaka, N. J. Chem. Soc. Chem. Commun. 1983, 1322.

150. Mori, S.; Aoyama, T.; Shioiri, T. Tetrahedron Lett. 1984, 25, 429.

\section{Author's Biography}

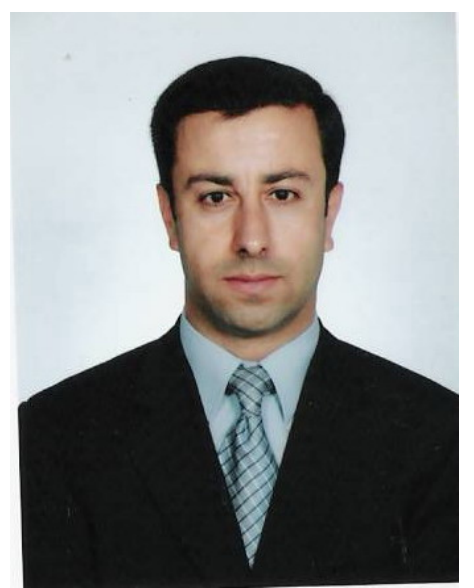


Tahir Daşkapan received his B.S., M.S. and Ph.D. degrees from Ankara University in 1990, 1993 and 1999, respectively. He performed research on the cyclization of organolithium reagents in W. F. Bailey's group at the University of Connecticut, USA (October 2001-August 2002) as a Scientific and Technical Research Council of Turkey (TUBITAK) fellow. He is currently a Professor of Chemistry at Ankara University, Science Faculty, Department of Chemistry-Turkey. His research interests involve reactions of organo-magnesium, -lithium, -zinc and -copper reagents. 